\title{
ADJUSTING DOSES AND SPLITING OF NITROGEN FERTILIZATION FOR EGYPTIAN HYPRID 1 RICE VARIETY UNDER BROADCASTED SEEDED RICE FOR OPTIMUM YIELD
}

\author{
Abdel-Fattah, A. G. ; M. M. El-Habashy ; W. M. El Khoby and \\ M. M. Shehab \\ Rice Res. and Training Center, Field Crops Res. Inst., Agric. Res. \\ Center, 33717 Sakha-Kafr El-Sheikh, Egypt
}

\begin{abstract}
In tow successive season's 2011 and 2012 two field experiments were ducted at the Rice Research and Training Center Farm, Sakha, Kafr El-Sheikh, Egypt. The investigation was carried out to study the effect of two nitrogen levels, i.e., 165 and $220 \mathrm{~kg} \mathrm{~N} / \mathrm{ha}$ and six times of nitrogen application, i.e., T1 ( $2 / 3$ as basal $+1 / 3$ at panicle initiation ), T2 ( $1 / 3$ as $B+1 / 3$ at mid-tillering $+1 / 3$ at $P . I)$, T3 $(1 / 2$ as $B+1 / 4$ at M.T $+1 / 4$ at P.I ), T4 ( $1 / 4$ as $B+1 / 4$ at M.T $+1 / 4$ at P.I $+1 / 4$ at booting $)$, T5 ( $1 / 4$ as $B+1 / 4$ at M.T $+1 / 4$ at BT $+1 / 4$ at complete heading $), T 6(1 / 4$ as $B+1 / 4$ at M.T + $1 / 4$ at $P . I+1 / 4$ at flowering ) of Egyptian hybrid 1 rice variety. The present study was laid out into split plot design with four replications. The most important findings of this study could be summarized as follows: Increasing $\mathrm{N}$-levels caused significant increases in growth, yield and its components for most studied traits. Time of nitrogen application significantly effect on growth and yield and its components for all studied traits. The best combination was adding $165 \mathrm{~kg} \mathrm{~N} / \mathrm{ha}$ in four splits (1/4 as B, 1/4 at M.T, $1 / 4$ at P.I, and $1 / 4$ at flowering) to produce optimum grain yield. From the obtained results, it can be recommended that for achievement of high yield production from Egyptian hybrid 1 rice variety when it grown under broadcast seeded rice and application of $\mathrm{N}$-fertilizer at the rate of $165 \mathrm{~kg} / \mathrm{ha}$, we must splitting nitrogen fertilizer in four equal doses i.e. as basal application, at mid-tillering stage, at panicle initiation stage and last at the flowering stage under these conditions of this study.
\end{abstract}

\section{INTRODUCTION}

Rice (Oryza sativa L.) is the world's most important staple food for more than two billion peoples in Asia and for hundred of millions in Africa and Latin America. Also, rice is considered one of the major food and export crop in Egypt and it is one of the most important and leading cereal crops. Annually, rice is grown in 1.35 million feddan in Egypt, and the total production is about 6 million metric tons.

The nitrogen deficiency in the Egyptian soils is one of major limiting factor for rice production, as nitrogen is an essential element to the rice plant, with about $75 \%$ of leaf $\mathrm{N}$ associated with chloroplasts, which are physiologically important in dry matter production through photosynthesis (Dalling, 1985). Rice plants require $\mathrm{N}$ during the vegetative stage to promote growth and tillering, which determines the potential number of panicles (Mae, 1997). 
Abdel-Fattah, A. G. et al.

Timing of fertilizer application may be the most critical factor in determining fertilizer uptake efficiency and crop yield. This is especially true for nitrogen fertilizer when fertilizer is applied near the time of physiological plant demand, therefore; the plant is able to be more efficiency uses the nutrients. The more nutrients that are used, the less opportunity there will be for loss. So that, it should have to manage the nitrogen fertilizer schedules to best match application with the plant demands. Split application of nitrogen as compared to single application can reduce potential nitrogen losses by up to $30 \%$ and reduce potential groundwater contamination. In order to obtain the maximum effect of nitrogen fertilizer it is not only important to resort correct dose of the fertilizer, but also to apply it in appropriate time (Thakur, 1993).

Introduction of hybrid rice is an important step towards augmentation of rice yield in Egypt. Hybrid rice proved more remunerative than high yielding commercial varieties. The yield advantage of hybrid rice is about $15-20 \%$ higher than that of the best high-yielding commercial varieties. Grain yield is a function of the number of panicles, grains/panicle and grains weight. Hybrid rice has bigger panicles and more spikelets/panicle but, less filled grain percentage probably due to higher nutrient demand during reproductive growth stage and hybrid rice requires different strategies for $\mathrm{N}$ management to maximize expression of yield advantage (Virmani, 1996).

Growth and development processes associated with higher grain yield of rice hybrids include a more vigorous and extensive root system ( $\mathrm{Li}, 1981)$, increased growth rate during vegetative growth (Yamauchi, 1994), more efficient sink formation and greater sink size (Kabaki, 1993), greater carbohydrate translocation from vegetative plant parts to the spikelets (Song et al., 1990), and larger leaf area index during the grain filling period.

The rice stem borer, Chilo agamemnon Bles attacks rice plants throughout the growing season. The damage of the insect appears as dead hearts in the vegetative stage and as white heads in the reproductive stage (Sherif, 2002). The increasing pressure on the land of the fast growing world's population had made it necessary to intensify rice production. The mineral fertilizer, particularly nitrogen is a very effective cultural practice to enhance rice productivity (Sarwar, 2011). Soil fertility practices can impact the physiological susceptibility of crop plants to insects by either affecting the resistance of individual plants to attack or by altering plant acceptability to certain herbivores (Chau and Heong, 2005).

Therefore, the present investigation was conducted to study and clarify the best method and time of nitrogen application to increase the nitrogen use efficiency and to reduce the amount of nitrogen fertilizer added for hybrid rice plants under broadcast seeded-rice.

Also the effects of nitrogenous fertilizer applied in split does at different growth stages on the severity of the rice stem borer, compared to application of the recommended dose as one application. 


\section{MATERIALS AND METHODS}

Two field experiments were conducted at the Experimental Farm of Rice Research and Training Center (RRTC), Sakha, Kafr El-Sheikh, Egypt, during 2011 and 2012 seasons. The experiments were conducted to study the response of Egyptian hybrid 1 rice variety to splitting of nitrogen fertilizer under broadcast seeded method. The preceding crop was wheat in both seasons.

The experiments were laid out in a split plot design with four replications. The plot area was $15 \mathrm{~m} 2$. The main plots were devoted to the two nitrogen levels i.e. 165 and $220 \mathrm{~kg} \mathrm{~N} / \mathrm{ha}$ in form of urea $(46.5 \% \mathrm{~N})$. The sub-plots were allocated to the six times of nitrogen application, i.e. :

Treatment $1(\mathrm{~T} 1)=2 / 3$ as basal $(\mathrm{B})$ and $1 / 3$ at panicle initiation $(\mathrm{PI})$.

Treatment $2(\mathrm{~T} 2)=1 / 3$ as $B+1 / 3$ at mid-tillering $(\mathrm{MT})$ and $1 / 3$ at PI.

Treatment $3(\mathrm{~T} 3)=1 / 2$ as $\mathrm{B}+1 / 4$ at $\mathrm{MT}$ and $1 / 4$ at $\mathrm{PI}$.

Treatment $4(T 4)=1 / 4$ as $B+1 / 4$ at $M T+1 / 4$ at $\mathrm{PI}$ and $1 / 4$ at booting (BT).

Treatment $5(T 5)=1 / 4$ as $B+1 / 4$ at $M T+1 / 4$ at $B T$ and $1 / 4$ at complete heading $(\mathrm{CH})$.

Treatment $6(\mathrm{~T} 6)=1 / 4$ as $\mathrm{B}+1 / 4$ at MT $+1 / 4$ at $\mathrm{PI}$ and $1 / 4$ at flowering $(\mathrm{F})$.

The experimental soil was clay in texture. The fine soil samples were mechanically and chemically analyzed following the methods described by Black et al. (1965). The results of mechanical and chemical soil properties are presented in Table (1). The permanent field was well-prepared, i.e., plowed twice followed by good wet leveling. Calcium super phosphate $(15.5 \%$ $\left.\mathrm{P}_{2} \mathrm{O}_{2}\right)$ was added at the rate of $240 \mathrm{~kg} / \mathrm{ha}(100 \mathrm{~kg} / \mathrm{fed}$.). Zinc sulphate $(28 \%$ $\left.\mathrm{ZnSO}_{4}\right)$ was applied at a rate of $(24 \mathrm{~kg} / \mathrm{ha})$. Potassium sulfate was applied at the rate of $120 \mathrm{~kg} \mathrm{~K} \mathrm{~K}_{2} \mathrm{O} / \mathrm{ha}(50 \mathrm{~kg} / \mathrm{fed})$ half of this dose was applied after land leveling and the other half was added at late booting stage. Nitrogen rate was determined for each plot according to the studied treatments. Seeding rate was $24 \mathrm{~kg} / \mathrm{ha}(10 \mathrm{~kg} / \mathrm{fed}$.).

Table 1. Mechanical and chemical analysis of the experimental soil sites in 2011 and 2012 seasons

\begin{tabular}{|l|c|c|}
\hline \multicolumn{1}{|c|}{ Soil analysis } & \multicolumn{2}{|c|}{ Seasons } \\
\cline { 2 - 3 } Mechanical analysis: & 2011 & 2012 \\
Sand \% & 14.6 & 12.7 \\
Silt \% & 30.5 & 31.8 \\
Clay \% & 56.1 & 54.6 \\
Texture & Clay & Clay \\
Chemical analysis: & 7.9 & 8.1 \\
PH & 1.9 & 2.1 \\
EC (ds/m) & 1.5 & 1.7 \\
Organic matter \% & 18.6 & 19.0 \\
Total N ppm & 16.0 & 17.2 \\
Available P ppm & 313 & 320 \\
Available K ppm & 0.8 & 0.9 \\
Available Zn pm & & \\
\hline
\end{tabular}


Abdel-Fattah, A. G. et al.

On May 25, seeds were manually broadcasted directly for each plot. The weeds were controlled chemically using Saturn $50 \%$ at the rate of 4.8 liters/ha (2liters/fed) dissolved in 250 liters of water and sprayed nine days after sowing. Plots were kept flooded till 2-3 weeks before harvesting. All other agronomic practices were followed as recommended during the growing season.

The samples were collected randomly from all treatments at panicle initiation (65days from transplanting) and at flowering stages(80days from transplanting), an area of $25 \times 25 \mathrm{~cm}\left(1 / 4 \mathrm{~m}^{2}\right)$ for estimating plant height, number of tillers $/ \mathrm{m}^{2}$,dry matter accumulation $\mathrm{g} / \mathrm{m}^{2}$, leaf area index (LAl) ,days to $50 \%$ heading, chlorophyll leaf content was estimated using chlorophyll meter (Model SPAD $=502$ ).

At maximum tillering stages (65days from transplanting), plants of half a square meter $\left(1 / 2 \mathrm{~m}^{2}\right)$ were cut at the soil surface from each experimental plot. Total number of tillers and those having dead heart symptom were recorded.The percentage of dead hearts was calculated. The same procedure was applied three weeks before harvest to calculate the percentage of white heads.

At harvest, plants of half a square meter $\left(1 / 2 \mathrm{~m}^{2}\right)$ were taken at random from each plot for determination the following characters: panicle length, number of panicles $/ \mathrm{m}^{2}$, number of filled grains/panicle, sterility percentage and 1000-grain weight $(\mathrm{g}) . \mathrm{In}$ addition, square meter from each plot were harvested and left for air-drying about three days. Grain yield "kg/ m" was determined (at grain moisture content of about 15\%), then, converted to estimate grain yield in $\mathrm{t} / \mathrm{ha}$, straw yield and harvest index.

All data collected were subjected to statistical analysis using ANOVA as described by Gomez and Gomez (1984). The treatment means were compared using Duncan's Multiple Range Test Duncan, 1955). All statistical analysis were performed using analysis of variance technique by means of "IRRISTAT" computer software package.

\section{RESULTS AND DISCUSSION}

\section{A. Growth characters:}

\section{A.1. Dry matter production $\left(\mathrm{g} / \mathrm{m}^{2}\right)$ :}

Regarding to the effect of nitrogen level on dry matter production $\left(\mathrm{g} / \mathrm{m}^{2}\right)$, data in Table 2 show that increasing nitrogen levels significantly increased dry matter production in the two seasons, respectively, at panicle initiation and flowering stage. These results might be due to the role of nitrogen in increasing leaf area, taller plants and high tillering. These results are in accordance with those obtained by El-Keredy et al. (2004), Salama (2005), Arafat (2007), Badawi, Shimaa (2008), Baba et al. (2010), Gorgy (2010), Sheta (2010) and Fukushima et al. (2011).

With concerning times of nitrogen application, data in Table 2 showed that significant effects were exerted by times of nitrogen application on dry matter production $\left(\mathrm{g} / \mathrm{m}^{2}\right)$ at panicle initiation and flowering in both seasons. The first time of nitrogen application $\mathrm{T} 1$ ( $2 / 3$ as basal $+1 / 3$ at panicle initiation) 
produced the highest values of dry matter at panicle initiation in both seasons, while, the lowest values of dry matter production at panicle initiation, in the first and second seasons, were obtained by the fifth treatment T5 (1/4 as basal $+1 / 4$ at MT $+1 / 4$ at BT $+1 / 4$ at complete heading).

Table2.Dry matter production and Leaf area index of hybrid rice as affected by nitrogen levels,times of nitrogen application and their interaction in 2011 and 2012 seasons.

\begin{tabular}{|c|c|c|c|c|c|c|c|c|}
\hline \multirow{3}{*}{ treatments } & \multicolumn{4}{|c|}{ Dry matt production(g/m²) } & \multicolumn{4}{|c|}{ Leaf area index(LAI) } \\
\hline & \multicolumn{2}{|c|}{$\begin{array}{c}\text { At panicle } \\
\text { initiation }\end{array}$} & \multicolumn{2}{|c|}{ At flowering } & \multicolumn{2}{|c|}{$\begin{array}{l}\text { At panicle } \\
\text { initiation }\end{array}$} & \multicolumn{2}{|c|}{ At flowering } \\
\hline & 2011 & 2012 & 2011 & 2012 & 2011 & 2012 & 2011 & 2012 \\
\hline $165 \mathrm{Kg} / \mathrm{ha}$ & $709.3 b$ & $720.9 b$ & 1792.6 & $1857.1 \mathrm{~b}$ & $6.11 \mathrm{~b}$ & $6.83 b$ & $6.21 b$ & 7.03 \\
\hline $220 \mathrm{Kg} / \mathrm{ha}$ & $757.3 a$ & $769.4 a$ & 1873.7 & $1943.6 a$ & $6.30 \mathrm{a}$ & $6.45 a$ & $7.26 a$ & 7.12 \\
\hline F. test & $\star *$ & ** & NS & ** & * & $\star *$ & ** & NS \\
\hline $\begin{array}{l}\text { Times of } \mathrm{N} \\
\text { application }\end{array}$ & & & & & & & & \\
\hline T1 & $788.1 \mathrm{a}$ & $801.9 a$ & $1702.4 f$ & $1775.3 f$ & $6.59 \mathrm{~b}$ & $6.70 \mathrm{~b}$ & $6.68 \mathrm{e}$ & $6.77 \mathrm{e}$ \\
\hline $\mathrm{T} 2$ & $757.8 \mathrm{c}$ & $768.4 b$ & $1861.1 \mathrm{c}$ & $1932.2 c$ & $6.77 a$ & $6.84 a$ & $7.03 c$ & $7.15 b$ \\
\hline T3 & $767.8 b$ & $778.1 \mathrm{~b}$ & $1801.9 d$ & $1868.4 d$ & $6.21 \mathrm{c}$ & $6.43 c$ & $6.86 d$ & $6.98 d$ \\
\hline T4 & $718.3 b$ & $719.9 c$ & $1920.3 b$ & $1977.8 b$ & $6.10 \mathrm{~d}$ & $6.11 \mathrm{e}$ & $7.17 b$ & $6.97 d$ \\
\hline T5 & $668.4 f$ & $688.1 d$ & $1741.8 \mathrm{e}$ & $1808.5 e$ & $5.48 \mathrm{e}$ & $5.61 f$ & $7.03 \mathrm{c}$ & $7.07 c$ \\
\hline T6 & $699.3 e$ & $714.8 \mathrm{c}$ & 1971.5a & $2039.7 a$ & $6.09 d$ & $6.31 d$ & $7.36 a$ & $7.53 a$ \\
\hline F.test & $\star \star$ & $\star *$ & ** & ** & ** & $\star \star$ & ** & ** \\
\hline NxT & * & $\star *$ & NS & NS & $\star *$ & ** & $\star \star$ & $\star \star$ \\
\hline
\end{tabular}

${ }^{*}{ }^{* \star}$ and $N . S$ indicate $P<0.05, P<0.01$ and not significant, respectively.

Means designated by the same letter are not significantly different at the $5 \%$ level by DMRT.

$\mathrm{T}_{1}=2 / 3$ as $\mathrm{B}$ (basal) $+1 / 3$ at $\mathrm{PI}$ (panicle initiation).

$T_{2}=1 / 3$ as $B+1 / 3$ at $M T$ (mid-tillering) $+1 / 3$ at $P$.

$T_{3}=1 / 2$ as $B+1 / 4$ at $M T+1 / 4$ at $P I$.

$\mathrm{T}_{4}=1 / 4$ as $\mathrm{B}+1 / 4$ at $\mathrm{MT}+1 / 4$ at $\mathrm{PI}+1 / 4$ at $\mathrm{BT}$ (booting).

$T_{5}=1 / 4$ as $B+1 / 4$ at $M T+1 / 4$ at $B T+1 / 4$ at $C H$ (complete heading).

$\mathrm{T}_{6}=1 / 4$ as $B+1 / 4$ at $M T+1 / 4$ at $\mathrm{PI}+1 / 4$ at $\mathrm{F}$ (flowering).

On the other hand, application of nitrogen into four splits T6 (1/4 as basal $+1 / 4$ at $\mathrm{MT}+1 / 4$ at $\mathrm{PI}+1 / 4$ at flowering) gave the maximum values of dry matter production at flowering in both seasons, while the lowest values of dry matter production at flowering in two seasons were produced when two-third of nitrogen as basal and one-third at panicle initiation was applied. These results are mainly attributed to the fact that nitrogen application along with the real-time paralleled with the plant nitrogen demand at various physiological growth stages especially along with first flowering encourage plant photosynthesis during plant growth through increases all vegetative growth characters which led finally to raising dry matter production at flowering .These results are in a good compatibility with Ebaid and El-Mowafi (2005) ,Arafat (2007), Sathiya and Ramesh (2009) and Nakano et al. (2011).

Data recorded in Table 3 show that the highest values of dry matter production in 2011 and 2012 seasons, respectively, were obtained by the first treatment $T_{1}(2 / 3$ as basal $+1 / 3$ at panicle initiation $)$ and highest 
Abdel-Fattah, A. G. et al.

nitrogen fertilizer level of $220 \mathrm{~kg} \mathrm{~N} / \mathrm{ha}$. The lowest values of dry matter production in both seasons were produced when the fifth treatment $T_{5}(1 / 4$ as basal $+1 / 4$ at $\mathrm{MT}+1 / 4$ at $\mathrm{BT}+1 / 4$ at complete heading) and lowest nitrogen fertilizer level of $165 \mathrm{~kg} \mathrm{~N} / \mathrm{ha}$ were applied.

The interaction between nitrogen level and time of nitrogen application had significantly affected on dry matter production at panicle initiation in both seasons, (Table 3).

Table3.Effect of the interaction between nitrogen levels and times of nitrogen application on dry matter production $(\mathrm{g} / \mathrm{m}+)$ at panicle initiation in 2011 season(

\begin{tabular}{|c|c|c|c|c|}
\hline \multirow{3}{*}{ Times of N-application } & \multicolumn{4}{|c|}{ Nitrogen levels $\mathbf{k g ~ N} / \mathbf{h a} \mathbf{~}$} \\
\cline { 2 - 5 } & $\mathbf{2 0 1 1}$ & $\mathbf{2 0 1 2}$ & $\mathbf{2 0 1 1}$ & $\mathbf{2 0 1 2}$ \\
\cline { 2 - 5 } & $\mathbf{1 6 5}$ & $\mathbf{2 2 0}$ & $\mathbf{1 6 5}$ & $\mathbf{2 2 0}$ \\
\hline $\mathrm{T}_{\mathbf{1}}$ & $760.93 \mathrm{~d}$ & $815.13 \mathrm{a}$ & $779.72 \mathrm{c}$ & $824.16 \mathrm{a}$ \\
\hline $\mathrm{T}_{\mathbf{2}}$ & $733.00 \mathrm{f}$ & $782.66 \mathrm{c}$ & $738.85 \mathrm{de}$ & $797.86 \mathrm{~b}$ \\
\hline $\mathrm{T}_{\mathbf{3}}$ & $741.51 \mathrm{e}$ & $794.08 \mathrm{~b}$ & $752.71 \mathrm{~d}$ & $803.48 \mathrm{~b}$ \\
\hline $\mathbf{T}_{\mathbf{4}}$ & $696.78 \mathrm{~h}$ & $739.77 \mathrm{e}$ & $708.18 \mathrm{f}$ & $731.55 \mathrm{e}$ \\
\hline $\mathrm{T}_{\mathbf{5}}$ & $648.60 \mathrm{k}$ & $688.69 \mathrm{i}$ & $661.48 \mathrm{~h}$ & $714.60 \mathrm{f}$ \\
\hline $\mathbf{T}_{\mathbf{6}}$ & $675.25 \mathrm{j}$ & $723.41 \mathrm{~g}$ & $684.70 \mathrm{~g}$ & $744.93 \mathrm{de}$ \\
\hline
\end{tabular}

${ }^{*}$, ** and $\mathrm{N} . \mathrm{S}$ indicate $\mathrm{P}<0.05, \mathrm{P}<0.01$ and not significant, respectively.

Means designated by the same letter are not significantly different at the $5 \%$ level by DMRT.

$T_{1}=2 / 3$ as $B$ (basal) $+1 / 3$ at $P I$ (panicle initiation).

$\mathrm{T}_{2}=1 / 3$ as $\mathrm{B}+1 / 3$ at $\mathrm{MT}$ (mid-tillering) $+1 / 3$ at $\mathrm{PI}$.

$\mathrm{T}_{3}=1 / 2$ as $\mathrm{B}+1 / 4$ at $\mathrm{MT}+1 / 4$ at $\mathrm{PI}$.

$\mathrm{T}_{4}=1 / 4$ as $\mathrm{B}+1 / 4$ at $\mathrm{MT}+1 / 4$ at $\mathrm{PI}+1 / 4$ at $\mathrm{BT}$ (booting).

$T_{5}=1 / 4$ as $B+1 / 4$ at $M T+1 / 4$ at $B T+1 / 4$ at $C H$ (complete heading).

$T_{6}=1 / 4$ as $B+1 / 4$ at $M T+1 / 4$ at $P I+1 / 4$ at $F$ (flowering).

\section{A.2. Leaf area index (LAI):}

Results in Table 2 clarified that increasing nitrogen fertilizer level significantly increased leaf area index at panicle initiation in both seasons. Nitrogen fertilization levels had significantly affected on leaf area index at flowering in 2011 season. These results may be due to the fact that nitrogen application encouraged growth of leaf area as an essential element, which plays a prominent role in building new merestimic cells, cell elongation and increasing photosynthesis activity of rice plants. The data are in complete conformity with those decided by El-Rewiny et al. (2004), Gorgy (2010) and Fukushima et al. (2011).

In relation to time of nitrogen application effect, data Table 2 indicated that time of nitrogen application had a significant effect on leaf area index at panicle initiation and flowering in both seasons. At panicle initiation, the highest values of leaf area index, in 2011 and 2012 seasons, were obtained when the second treatment (T2) $(1 / 3$ as basal $+1 / 3$ at mid-tillering $+1 / 3$ at panicle initiation) was applied. While the lowest values of leaf area index in 
both seasons, were produced when the fifth treatment T5 ( $1 / 4$ as basal $+1 / 4$ at $\mathrm{MT}+1 / 4$ at $\mathrm{BT}+1 / 4$ at complete heading) was applied. At flowering, from Table 4 , it is clear that the highest values of leaf area index in the first and second seasons were produced by the sixth treatment $(1 / 4$ as basal $+1 / 4$ at $\mathrm{MT}+1 / 4$ at $\mathrm{PI}+1 / 4$ at flowering). On the other hand, the lowest values of leaf area index in both seasons were obtained when the first time of nitrogen application (2/3 as basal $+1 / 3$ at panicle initiation) was applied. These results are in agreement with those of Edwin et al. (2004), Ebaid and El-Mowafi (2005), Mohammed (2006) and Arafat (2007)

The interaction between nitrogen levels and times of nitrogen application had significant effect on leaf area index (LAI) at panicle initiation and flowering in 2011 and 2012 as showed in Table (4).

Table4.Effect of the interaction between nitrogen levels and times of nitrogen application on leaf area index (LAl) at panicle initiation and flowering in 2011 and 2012 seasons.

\begin{tabular}{|l|c|c|c|c|c|c|c|c|}
\hline \multirow{2}{*}{$\begin{array}{l}\text { Times of N- } \\
\text { application }\end{array}$} & \multicolumn{3}{|c|}{ (LAl) at panicle initiation } & \multicolumn{4}{c|}{ (LAl) at flowering } \\
\cline { 2 - 8 } & $\mathbf{2 0 1 1}$ season & \multicolumn{2}{|c|}{$\mathbf{2 0 1 2}$ season } & \multicolumn{2}{c|}{$\mathbf{2 0 1 1}$ season } & \multicolumn{2}{c|}{$\mathbf{2 0 1 2}$ season } \\
\cline { 2 - 9 } & \multicolumn{3}{|c|}{ Nitrogen levels (kg N/ha) } & \multicolumn{3}{c|}{ Nitrogen levels (kg N/ha) } \\
\cline { 2 - 9 } & $\mathbf{1 6 5}$ & $\mathbf{2 2 0}$ & $\mathbf{1 6 5}$ & $\mathbf{2 2 0}$ & $\mathbf{1 6 5}$ & $\mathbf{2 2 0}$ & $\mathbf{1 6 5}$ & $\mathbf{2 2 0}$ \\
\hline T1 & $6.46 \mathrm{c}$ & $6.71 \mathrm{~b}$ & $6.57 \mathrm{~d}$ & $6.82 \mathrm{~b}$ & $6.97 \mathrm{f}$ & $6.70 \mathrm{i}$ & $7.06 \mathrm{e}$ & $6.80 \mathrm{f}$ \\
\hline T2 & $6.68 \mathrm{~b}$ & $6.85 \mathrm{a}$ & $6.74 \mathrm{c}$ & $6.93 \mathrm{a}$ & $7.21 \mathrm{~d}$ & $6.85 \mathrm{~h}$ & $7.27 \mathrm{c}$ & $7.02 \mathrm{e}$ \\
\hline T3 & $6.14 \mathrm{ef}$ & $6.27 \mathrm{~d}$ & $6.31 \mathrm{f}$ & $6.55 \mathrm{~d}$ & $7.08 \mathrm{e}$ & $6.58 \mathrm{j}$ & $7.16 \mathrm{~d}$ & $6.35 \mathrm{~h}$ \\
\hline T4 & $6.07 \mathrm{~g}$ & $6.13 \mathrm{ef}$ & $5.92 \mathrm{~h}$ & $6.29 \mathrm{f}$ & $7.44 \mathrm{~b}$ & $6.90 \mathrm{~g}$ & $6.89 \mathrm{~g}$ & $7.18 \mathrm{~d}$ \\
\hline T5 & $5.34 \mathrm{i}$ & $5.62 \mathrm{~h}$ & $5.53 \mathrm{j}$ & $5.68 \mathrm{i}$ & $7.27 \mathrm{c}$ & $6.78 \mathrm{hi}$ & $7.20 \mathrm{~d}$ & $6.93 \mathrm{f}$ \\
\hline T6 & $5.98 \mathrm{~g}$ & $6.20 \mathrm{e}$ & $6.19 \mathrm{~g}$ & $6.42 \mathrm{e}$ & $7.59 \mathrm{a}$ & $7.12 \mathrm{de}$ & $7.67 \mathrm{a}$ & $7.38 \mathrm{~b}$ \\
\hline
\end{tabular}

*, ** and N.S indicate $\mathbf{P}<0.05, P<0.01$ and not significant, respectively.

Means designated by the same letter are not significantly different at the $5 \%$ level by DMRT.

$T 1=2 / 3$ as $B$ (basal) $+1 / 3$ at $P I$ (panicle initiation).

$\mathrm{T} 2=1 / 3$ as $B+1 / 3$ at $\mathrm{MT}$ (mid-tillering) $+1 / 3$ at $\mathrm{PI}$.

T3=1/2 as $B+1 / 4$ at $M T+1 / 4$ at $P I$.

$\mathrm{T} 4=1 / 4$ as $B+1 / 4$ at $M T+1 / 4$ at $P I+1 / 4$ at $B T$ (booting).

$T 5=1 / 4$ as $B+1 / 4$ at $M T+1 / 4$ at $B T+1 / 4$ at $C H$ (complete heading).

$\mathrm{T} 6=1 / 4$ as $B+1 / 4$ at $\mathrm{MT}+1 / 4$ at $\mathrm{PI}+1 / 4$ at $\mathrm{F}$ (flowering).

\section{A.3. Chlorophyll content:}

Data results in table 5 clearly showed that nitrogen fertilization significantly affected the chlorophyll content in flag leaf in 2011and 2012seasons. Therefore, increasing nitrogen fertilizer levels up to $220 \mathrm{~kg} \mathrm{~N} / \mathrm{ha}$ increased chlorophyll content (\%) in flag leaf in both seasons. On the contrary, the lowest values of chlorophyll content in both seasons, were obtained when $165 \mathrm{~kg} \mathrm{~N} / \mathrm{ha}$ was used. These results might be due to the role of nitrogen as an essential element for chlorophyll formation. These findings are in line with those reported by Chang et al. (2008) and Sheta (2010). 
Abdel-Fattah, A. G. et al.

Table5. Chlorophyll content in flag leaf and Days to $50 \%$ heading of hybrid rice as affected by nitrogen level, time of nitrogen application and their interaction in 2009 and 2010 seasons.

\begin{tabular}{|c|c|c|c|c|}
\hline \multirow{2}{*}{$\begin{array}{c}\text { Nitrogen } \\
\text { levels }\end{array}$} & \multicolumn{2}{|c|}{ Chlorophyll content } & \multicolumn{2}{c|}{ Days to $\mathbf{5 0 \%}$ heading } \\
\cline { 2 - 5 } & $\mathbf{2 0 1 1}$ & $\mathbf{2 0 1 2}$ & $\mathbf{2 0 1 1}$ & $\mathbf{2 0 1 2}$ \\
\hline $165 \mathrm{Kg} / \mathrm{ha}$ & $38.77 \mathrm{~b}$ & $39.27 \mathrm{~b}$ & $86.92 \mathrm{~b}$ & $87.33 \mathrm{~b}$ \\
\hline $220 \mathrm{Kg} / \mathrm{ha}$ & $39.60 \mathrm{a}$ & $40.15 \mathrm{a}$ & $87.83 \mathrm{a}$ & $88.50 \mathrm{a}$ \\
\hline F. test & ${ }^{*}$ & ${ }^{* *}$ & & \\
\hline $\begin{array}{c}\text { Times of N } \\
\text { application }\end{array}$ & & & & \\
\hline T1 & $37.23 \mathrm{f}$ & $37.69 \mathrm{f}$ & $86.00 \mathrm{~d}$ & $86.39 \mathrm{e}$ \\
\hline T2 & $38.62 \mathrm{~d}$ & $39.04 \mathrm{~d}$ & $86.88 \mathrm{c}$ & $87.63 \mathrm{~cd}$ \\
\hline T3 & $37.76 \mathrm{e}$ & $38.27 \mathrm{e}$ & $86.62 \mathrm{c}$ & $87.00 \mathrm{~d}$ \\
\hline T4 & $40.83 \mathrm{~b}$ & $41.38 \mathrm{~b}$ & $88.03 \mathrm{~b}$ & $88.71 \mathrm{~b}$ \\
\hline T5 & $39.27 \mathrm{c}$ & $39.93 \mathrm{c}$ & $87.16 \mathrm{bc}$ & $88.00 \mathrm{bc}$ \\
\hline T6 & $41.39 \mathrm{a}$ & $41.95 \mathrm{a}$ & $88.88 \mathrm{a}$ & $89.75 \mathrm{a}$ \\
\hline F.test & ${ }^{* *}$ & ${ }^{* *}$ & ${ }^{* *}$ & $\mathrm{NS}$ \\
\hline $\mathrm{NxT}$ & $\mathrm{NS}$ & ${ }^{*}$ & $\mathrm{NS}$ & $\mathrm{NS}$ \\
\hline
\end{tabular}

${ }^{*},{ }^{\star \star}$ and $\mathrm{N} . \mathrm{S}$ indicate $\mathrm{P}<0.05, \mathrm{P}<0.01$ and not significant, respectively.

Means designated by the same letter are not significantly different at the $5 \%$ level by

DMRT.

$\mathrm{T} 1=2 / 3$ as $\mathrm{B}$ (basal) $+1 / 3$ at $\mathrm{PI}$ (panicle initiation)

T2 $=1 / 3$ as $B+1 / 3$ at $M T$ (mid-tillering) $+1 / 3$ at $P$.

T3 $=1 / 2$ as $B+1 / 4$ at $M T+1 / 4$ at $P I$.

$\mathrm{T} 4=1 / 4$ as $\mathrm{B}+1 / 4$ at $\mathrm{MT}+1 / 4$ at $\mathrm{PI}+1 / 4$ at $\mathrm{BT}$ (booting).

T5=1/4 as $B+1 / 4$ at $M T+1 / 4$ at $B T+1 / 4$ at $C H$ (complete heading).

$\mathrm{T} 6=1 / 4$ as $B+1 / 4$ at $M T+1 / 4$ at $\mathrm{PI}+1 / 4$ at $\mathrm{F}$ (flowering)

Regarding to time of nitrogen application effect, data in Table 5 claimed that times of nitrogen application had a significant effect on chlorophyll content in flag leaf in 2011 and 2012 seasons. The sixth treatment (T6) of nitrogen application was found to be more effective in enhancing chlorophyll content in flag leaf over other treatments in both seasons. High values of chlorophyll content were recorded in the first and second seasons, respectively, when the sixth treatment T6 (1/4 as basal $+1 / 4$ at MT + 1/4 at $\mathrm{PI}+1 / 4$ at flowering) was applied.

On the other hand, low values of chlorophyll content in both seasons were produced when two- third of nitrogen as basal and one-third at panicle initiation (T1) was applied. It is obviously that the application of nitrogen at complete heading stage might be beneficial on chlorophyll content in flag leaf through keeping the leaves green for a long time in addition to the nitrogen supply at the great role in this concern. These results are in harmony with those reported by Edwin et al. (2004) and Arafat (2007).

On the other hand, the interaction between the two factors under study (nitrogen level and time of nitrogen application) had a significant effect on chlorophyll content in flag leaf in the second season (Table 5).

Data in Table 6 show that the highest value of chlorophyll content during the second season was recorded by the sixth treatment T6 (1/4 as basal $+1 / 4$ at MT $+1 / 4$ at $\mathrm{PI}+1 / 4$ at flowering) and fertilized by $220 \mathrm{~kg} \mathrm{~N} / \mathrm{ha}$ .The lowest value of chlorophyll content during the second season was produced when the first application of nitrogen( $2 / 3$ as basal $+1 / 3$ at panicle initiation) was used under $165 \mathrm{~kg} \mathrm{~N} / \mathrm{ha}$ level of nitrogen fertilization. 
Table 6. Effect of the interaction between nitrogen levels and times of nitrogen application on chlorophyll content in flag leaf in 2012season.

\begin{tabular}{|c|c|c|}
\hline \multirow{2}{*}{ Times of N-application } & \multicolumn{2}{|c|}{ 2012 season } \\
\cline { 2 - 3 } & \multicolumn{2}{|c|}{ Nitrogen levels (kg N/ha) } \\
\cline { 2 - 3 } & $\mathbf{1 6 5}$ & $\mathbf{2 2 0}$ \\
\hline T1 & $37.49 \mathrm{~h}$ & $37.90 \mathrm{~g}$ \\
\hline T2 & $38.56 \mathrm{f}$ & $38.52 \mathrm{e}$ \\
\hline T3 & $37.95 \mathrm{~g}$ & $41.90 \mathrm{~b}$ \\
\hline T4 & $40.86 \mathrm{~d}$ & $40.55 \mathrm{~d}$ \\
\hline T5 & $39.32 \mathrm{e}$ & $42.43 \mathrm{a}$ \\
\hline T6 & $41.47 \mathrm{c}$ & \\
\hline
\end{tabular}

*, ** and N.S indicate $\mathrm{P}<0.05, \mathrm{P}<0.01$ and not significant, respectively.

Means designated by the same letter are not significantly different at the $5 \%$ level by DMRT.

$\mathrm{T} 1=2 / 3$ as $\mathrm{B}$ (basal) $+1 / 3$ at $\mathrm{PI}$ (panicle initiation).

T2=1/3 as $B+1 / 3$ at MT (mid-tillering) $+1 / 3$ at PI.

T3=1/2 as $B+1 / 4$ at $M T+1 / 4$ at $P I$.

$\mathrm{T} 4=1 / 4$ as $\mathrm{B}+1 / 4$ at $\mathrm{MT}+1 / 4$ at $\mathrm{PI}+1 / 4$ at $\mathrm{BT}$ (booting).

T5 $=1 / 4$ as $B+1 / 4$ at $M T+1 / 4$ at $B T+1 / 4$ at $C H$ (complete heading).

T6=1/4 as $B+1 / 4$ at $M T+1 / 4$ at $P I+1 / 4$ at $F$ (flowering).

\section{A.5. Days to $50 \%$ heading:}

Data showed that varying nitrogen level had observable significant effect on days of $50 \%$ heading (Table5). Increasing nitrogen levels delayed the heading time. The longest period from sowing to heading in the first and second seasons, were produced by the higher nitrogen level $(220 \mathrm{~kg} \mathrm{~N} / \mathrm{ha})$. However, the lower nitrogen level ( $165 \mathrm{~kg} \mathrm{~N} / \mathrm{ha}$ ) gave the shortest period from sowing to heading. The late heading due to high rate of $\mathrm{N}$ may be due to the increase in vegetative growth stage consequently the late in the emergence of panicle. Such results are in accordance with those found by El-Keredy et al. (2004), Ebaid (2005b), Mikhael (2010) and Petroudi et al. (2011). Significant differences were observed between the six tested treatments of nitrogen application as for as the days to $50 \%$ heading is concerned Table (5).The data indicated that applying small dose of nitrogen at beginning of heading delay the heading time by way, nitrogen splitting in four equal doses one of them at $50 \%$ heading was more effective in delaying heading time that might be increased the dry matter production which attributed to high grain yield of hybrid rice. Whereas, the longest period from sowing to heading in both seasons, were produced with the sixth treatment $T 6(1 / 4$ as basal $+1 / 4$ at MT $+1 / 4$ at $\mathrm{PI}+1 / 4$ at flowering) was applied. The short desirable period from sowing to heading in both seasons, were obtained from the first treatment T1 ( $2 / 3$ as basal $+1 / 3$ at panicle initiation) was applied. Similar findings have been found by Ebaid and El-Mowafi (2005), Mohammed (2006) and El-Kallawy (2008).

Concerning the interaction effect, Table (5) indicated that there were no significant difference were recorded between the two factors on days to $50 \%$ heading in both seasons. 


\section{A.4 Dead heart and White head\%}

Data presented in Table 7 show the effect of nitrogen rates and times of application on the level of rice infestation by rice stem borer, Chilo agamemnon Bles.

Dead heart percentages were lower $(5.50-5.55 \%)$ in rice plots treated with $165 \mathrm{KgN} / \mathrm{ha}$, as compared to $6.43-6.45 \%$ in plot treated with $220 \mathrm{kgN} / \mathrm{ha}$. The same trend appeared with white heads. At $165 \mathrm{kgN} / \mathrm{ha}$, the infestatim ranged $12.74-12.77 \%$ white head, and increased to $13.63-13.66 \%$ white head at the higher rate of nitrogen $(220 \mathrm{kgN} / \mathrm{ha})$. Such results are in accordance with those found by Sherif (2002) and Sarwar (2011).The differences were highly significant in case of dead hearts and white heads.

Time of nitrogen application resulted in highly significant differences among dead hearts and white heads recorded at different nitrogen application combination. Both dead hearts and white heads were higher in T4, T5and T6 than in T1, T2 and T3. This means that fertilizing rice plots at booting and complete flowering enhances the infestation by the rice stem borer, that are expressed as high levels of white heads.

Table7. Dead heart and White head\% of hybrid rice as affected by nitrogen levels, times of nitrogen application and their interaction in 2011 and 2012 seasons.

\begin{tabular}{|c|c|c|c|c|}
\hline \multirow{2}{*}{$\begin{array}{l}\text { characters } \\
\text { treatments }\end{array}$} & \multicolumn{2}{|c|}{ Dead heart\% } & \multicolumn{2}{|c|}{ White head\% } \\
\hline & 2011 & 2012 & 2011 & 2012 \\
\hline $165 \mathrm{Kg} / \mathrm{ha}$ & $5.55 b$ & $5.50 b$ & $12.74 b$ & $12.77 b$ \\
\hline $220 \mathrm{Kg} / \mathrm{ha}$ & $6.43 a$ & $6.45 a$ & 13.63a & $13.66 a$ \\
\hline F. test & ** & ** & ** & ** \\
\hline \multicolumn{5}{|l|}{ Time of $\mathrm{N}$ application } \\
\hline T1 & $5.20 f$ & $5.24 \mathrm{e}$ & $7.79 f$ & $7.80 f$ \\
\hline T2 & $5.69 e$ & $5.54 d$ & $13.62 \mathrm{e}$ & $13.66 \mathrm{e}$ \\
\hline T3 & $5.78 d$ & $5.79 c$ & $13.96 \mathrm{~d}$ & $13.98 d$ \\
\hline $\mathrm{T} 4$ & $6.29 \mathrm{c}$ & $6.27 b$ & $14.47 \mathrm{c}$ & $14.52 \mathrm{c}$ \\
\hline T5 & $6.43 b$ & $6.44 a b$ & $14.60 \mathrm{~b}$ & $14.62 b$ \\
\hline T6 & $6.54 a$ & $6.56 a$ & $14.68 a$ & $14.71 \mathrm{a}$ \\
\hline F.test & ** & ** & ** & ** \\
\hline NxT & ** & * & ** & ** \\
\hline
\end{tabular}

${ }^{*},{ }^{* \star}$ and $\mathrm{N} . \mathrm{S}$ indicate $\mathrm{P}<0.05, \mathrm{P}<0.01$ and not significant, respectively.

Means designated by the same letter are not significantly different at the $5 \%$ level by DMRT.

$\mathrm{T} 1=2 / 3$ as $\mathrm{B}$ (basal) $+1 / 3$ at $\mathrm{PI}$ (panicle initiation).

$\mathrm{T} 2=1 / 3$ as $B+1 / 3$ at $\mathrm{MT}$ (mid-tillering) $+1 / 3$ at $\mathrm{PI}$.

T3=1/2 as $B+1 / 4$ at $M T+1 / 4$ at $P I$.

T4=1/4 as $B+1 / 4$ at $M T+1 / 4$ at $P I+1 / 4$ at $B T$ (booting)

T5=1/4 as $B+1 / 4$ at $M T+1 / 4$ at $B T+1 / 4$ at $C H$ (complete heading).

T6=1/4 as $B+1 / 4$ at $M T+1 / 4$ at $P I+1 / 4$ at $F$ (flowering)

Data in Table 8 show the effect of interaction between applied nitrogen levels and their time of applications on the rice infestatim by rice stem borer. The infestations by dead hearts were highest when $220 \mathrm{kgN} / \mathrm{ha}$ was applied; particularly in the late stages of rice growth $(6.81-7.14 \%)$ in case of T4, T5 andT6 with $220 \mathrm{kgN} / \mathrm{ha}$. Also, the white head percentages were highest (15.10 and 15.13\%) at T6 with $220 \mathrm{kgN} / \mathrm{ha}$ in 2011 and 2012 seasons, 
respectively. These results had been reported by Chau and Heong (2005) and Sarwar (2011)

Table8. Effect of the interaction between nitrogen levels and times of nitrogen application on Dead heart and White head\% in 2011 and 2012 seasons.

\begin{tabular}{|l|c|c|c|c|c|c|c|c|}
\hline \multirow{2}{*}{$\begin{array}{l}\text { Times of N-a } \\
\text { application }\end{array}$} & \multicolumn{4}{|c|}{ Dead heart\% } & \multicolumn{4}{c|}{ White head\% } \\
\cline { 2 - 8 } & $\mathbf{2 0 1 1}$ season & \multicolumn{2}{|c|}{$\mathbf{2 0 1 2}$ season } & \multicolumn{2}{c|}{ 2011 season } & \multicolumn{2}{c|}{ 2012 season } \\
\cline { 2 - 8 } & \multicolumn{3}{|c|}{ Nitrogen levels (kg N/ha) } & \multicolumn{3}{c|}{ Nitrogen level (kg N/ha) } \\
\cline { 2 - 8 } & 165 & 220 & 165 & 220 & 165 & 220 & 165 & 220 \\
\hline T1 & $4.95 \mathrm{~h}$ & $5.45 \mathrm{~h}$ & $4.96 \mathrm{~g}$ & $5.51 \mathrm{~g}$ & $7.44 \mathrm{j}$ & $8.14 \mathrm{j}$ & $7.45 \mathrm{j}$ & $8.15 \mathrm{j}$ \\
\hline T2 & $5.30 \mathrm{e}$ & $6.07 \mathrm{e}$ & $5.00 \mathrm{c}$ & $6.08 \mathrm{c}$ & $13.11 \mathrm{f}$ & $14.13 \mathrm{f}$ & $13.16 \mathrm{f}$ & $14.15 \mathrm{f}$ \\
\hline T3 & $5.39 \mathrm{~d}$ & $6.16 \mathrm{~d}$ & $5.41 \mathrm{c}$ & $6.18 \mathrm{c}$ & $13.41 \mathrm{~d}$ & $14.51 \mathrm{~d}$ & $13.44 \mathrm{~d}$ & $14.51 \mathrm{~d}$ \\
\hline T4 & $5.76 \mathrm{c}$ & $6.82 \mathrm{c}$ & $5.73 \mathrm{~b}$ & $6.81 \mathrm{~b}$ & $14.01 \mathrm{c}$ & $14.93 \mathrm{c}$ & $14.06 \mathrm{c}$ & $14.98 \mathrm{c}$ \\
\hline T5 & $5.90 \mathrm{~b}$ & $6.96 \mathrm{~b}$ & $5.90 \mathrm{ab}$ & $6.97 \mathrm{ab}$ & $14.23 \mathrm{~b}$ & $14.98 \mathrm{~b}$ & $14.22 \mathrm{~b}$ & $15.02 \mathrm{~b}$ \\
\hline T6 & $5.97 \mathrm{a}$ & $7.11 \mathrm{a}$ & $5.98 \mathrm{a}$ & $7.14 \mathrm{a}$ & $14.26 \mathrm{a}$ & $15.10 \mathrm{a}$ & $14.28 \mathrm{a}$ & $15.13 \mathrm{a}$ \\
\hline
\end{tabular}

*, ** and N.S indicate $P<0.05, P<0.01$ and not significant, respectively.

Means designated by the same letter are not significantly different at the $5 \%$ level by DMRT.

$\mathrm{T} 1=2 / 3$ as $\mathrm{B}$ (basal) $+1 / 3$ at $\mathrm{PI}$ (panicle initiation).

$T 2=1 / 3$ as $B+1 / 3$ at $M T$ (mid-tillering) $+1 / 3$ at $P I$.

$\mathrm{T} 3=1 / 2$ as $\mathrm{B}+1 / 4$ at $\mathrm{MT}+1 / 4$ at $\mathrm{PI}$.

$\mathrm{T} 4=1 / 4$ as $B+1 / 4$ at $M T+1 / 4$ at $P I+1 / 4$ at $B T$ (booting).

$T 5=1 / 4$ as $B+1 / 4$ at $M T+1 / 4$ at $B T+1 / 4$ at $C H$ (complete heading).

T6=1/4 as $B+1 / 4$ at $M T+1 / 4$ at $P I+1 / 4$ at $F$ (flowering)

\section{A.6. Plant height at harvest (cm):}

Regarding the impact of nitrogen fertilizer levels on plant height, the two tested methods of nitrogen levels had a significant effect on rice plant height in both study seasons (Table9). Increasing nitrogen level significantly increased the plant height. The tallest plants in both seasons, were obtained when $220 \mathrm{~kg} \mathrm{~N} / \mathrm{ha}$ was used. The desirable shortest plants were obtained when the treatment of $165 \mathrm{~kg} \mathrm{~N} / \mathrm{ha}$ were added in both seasons. It is well knows that nitrogen encourages and accelerates cell division and cell elongation of plants. The favourable effect of nitrogen application on plant height was reported by El-Rewiny et al. (2004), Gewally (2006), and Gorgy (2010).

Concerning to times of nitrogen application, data in Table 9 showed that significant effects were observed by time of nitrogen application on plant height at harvest in both seasons. The sixth treatment of nitrogen application (T6) surpassed the other methods of nitrogen application in this trait. The undesirable tallest plants were produced from the sixth treatment T6 (1/4 as basal $+1 / 4$ at $M T+1 / 4$ at $P I+1 / 4$ at flowering), while, the desirable shortest plants were produced from the first treatment $T 1$ (2/3 as basal $+1 / 3$ at panicle initiation) was applied. The obtained results could be summarized as that nitrogen application is considered a suitable tactic which could continuously supply nitrogen at each growth stage according to plant demand. These means, nitrogen application at heading stage significantly increased growth characters for instance plant height. These results are in harmony with those recorded by Arafat (2007), El-Kallawy (2008) and Sathiya and Ramesh (2009). 


\section{A.7. Number of tillers $/ \mathrm{m}^{2}$ :}

Data cleared that nitrogen level had highly significantly effects on number of tillers $/ \mathrm{m}^{2}$ in both seasons (Table9). Increasing N-levels significantly increased number of tillers $/ \mathrm{m}^{2}$ in both seasons. Each increment of applied nitrogen resulted in a significant increase in number of tillers $/ \mathrm{m}^{2}$. The highest number of tillers $/ \mathrm{m}^{2}$ was produced with $220 \mathrm{~kg} \mathrm{~N} / \mathrm{ha}$. Otherwise, the lowest number of tillers $/ \mathrm{m}^{2}$ was obtained from $165 \mathrm{~kg} \mathrm{~N} / \mathrm{ha}$. Increasing tillers number due to raising $\mathrm{N}$ level might be due to the prominent role of nitrogen on vegetative growth and tillering capacity. The present findings are in agreement with those obtained by Salama (2005), Rahman et al. (2007) and Baba et al. (2010).

Table9. Plant height at harvest (cm) and number of tillers $/ \mathrm{m}^{2}$ of hybrid rice as affected by nitrogen levels, times of nitrogen application and their interaction in 2011 and 2012 seasons.

\begin{tabular}{|c|c|c|c|c|}
\hline \multirow{2}{*}{$\begin{array}{l}\text { Nitrogen } \\
\text { levels }\end{array}$} & \multicolumn{2}{|c|}{ Plant height(cm) } & \multicolumn{2}{|c|}{ Number of tillers/m² } \\
\hline & 2011 & 2012 & 2011 & 2012 \\
\hline $165 \mathrm{Kg} / \mathrm{ha}$ & $96.26 \mathrm{~b}$ & $100.38 \mathrm{~b}$ & $598.00 \mathrm{~b}$ & $615.33 \mathrm{~b}$ \\
\hline $220 \mathrm{Kg} / \mathrm{ha}$ & $101.40 \mathrm{a}$ & $105.32 \mathrm{a}$ & $616.00 \mathrm{a}$ & $632.67 \mathrm{a}$ \\
\hline F. test & $\star \star *$ & ** & ** & ** \\
\hline $\begin{array}{l}\text { Times of } \\
\text { application }\end{array}$ & & & & \\
\hline T1 & $94.41 \mathrm{~d}$ & $97.23 \mathrm{~d}$ & $590.00 \mathrm{c}$ & $604.00 \mathrm{c}$ \\
\hline $\mathrm{T} 2$ & $98.58 \mathrm{c}$ & $103.69 \mathrm{~b}$ & $604.00 \mathrm{~b}$ & $622.00 \mathrm{~b}$ \\
\hline T3 & $97.99 \mathrm{c}$ & $102.73 \mathrm{~b}$ & $600.00 \mathrm{~b}$ & $616.00 \mathrm{~b}$ \\
\hline T4 & $101.98 \mathrm{~b}$ & $104.18 \mathrm{~b}$ & $626.00 \mathrm{a}$ & $644.00 \mathrm{a}$ \\
\hline T5 & $96.41 \mathrm{c}$ & $99.94 \mathrm{c}$ & $590.00 \mathrm{c}$ & $608.00 \mathrm{c}$ \\
\hline T6 & $104.11 \mathrm{a}$ & $107.03 \mathrm{a}$ & $632.00 \mathrm{a}$ & $650.00 \mathrm{a}$ \\
\hline F.test & $\star \star$ & $\star \star$ & $\star \star$ & $\star \star$ \\
\hline $\mathrm{NxT}$ & NS & NS & NS & $\star \star$ \\
\hline
\end{tabular}

${ }^{*}$, ** and N.S indicate $P<0.05, P<0.01$ and not significant, respectively.

Means designated by the same letter are not significantly different at the $5 \%$ level by DMRT.

$\mathrm{T}_{1}=2 / 3$ as $\mathrm{B}$ (basal) $+1 / 3$ at $\mathrm{PI}$ (panicle initiation).

$T_{2}=1 / 3$ as $B+1 / 3$ at $M T$ (mid-tillering) $+1 / 3$ at $P I$.

$\mathrm{T}_{3}=1 / 2$ as $B+1 / 4$ at $M T+1 / 4$ at $\mathrm{PI}$.

$\mathrm{T}_{4}=1 / 4$ as $B+1 / 4$ at $M T+1 / 4$ at $\mathrm{PI}+1 / 4$ at $B T$ (booting).

$T_{5}=1 / 4$ as $B+1 / 4$ at $M T+1 / 4$ at $B T+1 / 4$ at $\mathrm{CH}$ (complete heading).

$\mathrm{T}_{6}=1 / 4$ as $\mathrm{B}+1 / 4$ at $\mathrm{MT}+1 / 4$ at $\mathrm{PI}+1 / 4$ at $\mathrm{F}$ (flowering).

Data presented in Table 9 show that time of nitrogen application had distinct significant effect on number of tillers $/ \mathrm{m}^{2}$ in both seasons. Both times of nitrogen application $\left(T_{6} \& T_{4}\right)$ did not differ significantly in this concern. They gave the highest number of tillers $/ \mathrm{m}^{2}$ in the first and second seasons, respectively. The treatments $\left(T_{1} \& T_{5}\right)$ produced the lowest number of tillers $/ \mathrm{m}^{2}$ without significant differences between them. These results could be mainly attributed to the fact that multiple schedules of nitrogen application especially along with the beginning of flowering improved the number of tillers $/ \mathrm{m}^{2}$ by continuously abundant exit for nitrogen during all critical growth 
stages which the plant had edacity demand from nitrogen then finally reduce the mortality percentage at flowering and stabilize the tiller numbers $/ \mathrm{m}^{2}$. Similar results were also reported by Ebaid and El-Mowafi (2005), El-Kallawy (2008) and Sathiya and Ramesh (2009).

The interaction between nitrogen level and time of nitrogen application had significant effect on number of tillers $/ \mathrm{m}^{2}$ in the second season as showed in Table 9.

From Table 10, the results revealed that the more number of tillers $/ \mathrm{m}^{2}$ in 2012 season was obtained by the highest nitrogen fertilizer level $(220 \mathrm{~kg} \mathrm{~N} / \mathrm{ha})$ and the sixth treatment $\mathrm{T}_{6}(1 / 4$ as basal $+1 / 4$ at $\mathrm{MT}+1 / 4$ at $\mathrm{PI}+$ $1 / 4$ at flowering). The lowest number of tillers $/ \mathrm{m}^{2}$ in the second season was produced with the first treatment $T_{1}(2 / 3$ as basal $+1 / 3$ at panicle initiation) and $165 \mathrm{~kg} \mathrm{~N} / \mathrm{ha}$ of nitrogen fertilization

Table10. Effect of the interaction between nitrogen levels and times of nitrogen application on number of tillers $/ \mathrm{m}^{2}$ in 2012 season.

\begin{tabular}{|c|c|c|}
\hline \multirow{2}{*}{ Times of N-application } & \multicolumn{2}{|c|}{ 2012 season } \\
\cline { 2 - 3 } & \multicolumn{2}{|c|}{ Nitrogen levels (kg N/ha) } \\
\cline { 2 - 3 } & $592.00 \mathrm{~h}$ & $\mathbf{2 2 0}$ \\
\hline $\mathrm{T}_{1}$ & $616.00 \mathrm{ef}$ & $616.00 \mathrm{ef}$ \\
\hline $\mathrm{T}_{2}$ & $608.00 \mathrm{fg}$ & $628.00 \mathrm{~d}$ \\
\hline $\mathrm{T}_{3}$ & $640.00 \mathrm{bc}$ & $648.00 \mathrm{~d}$ \\
\hline $\mathrm{T}_{4}$ & $604.00 \mathrm{~g}$ & $612.00 \mathrm{fg}$ \\
\hline $\mathrm{T}_{5}$ & $632.00 \mathrm{~cd}$ & $668.00 \mathrm{a}$ \\
\hline $\mathrm{T}_{6}$ & & 6 \\
\hline
\end{tabular}

${ }^{\star},{ }^{\star \star}$ and $\mathrm{N} . \mathrm{S}$ indicate $\mathrm{P}<0.05, \mathrm{P}<0.01$ and not significant, respectively.

Means designated by the same letter are not significantly different at the $5 \%$ level by DMRT.

$\mathrm{T}_{1}=2 / 3$ as $\mathrm{B}$ (basal) $+1 / 3$ at $\mathrm{PI}$ (panicle initiation).

$T_{2}=1 / 3$ as $B+1 / 3$ at $M T$ (mid-tillering) $+1 / 3$ at $P I$.

$\mathrm{T}_{3}=1 / 2$ as $\mathrm{B}+1 / 4$ at $\mathrm{MT}+1 / 4$ at $\mathrm{PI}$.

$\mathrm{T}_{4}=1 / 4$ as $\mathrm{B}+1 / 4$ at $\mathrm{MT}+1 / 4$ at $\mathrm{PI}+1 / 4$ at $\mathrm{BT}$ (booting).

$\mathrm{T}_{5}=1 / 4$ as $\mathrm{B}+1 / 4$ at $\mathrm{MT}+1 / 4$ at $\mathrm{BT}+1 / 4$ at $\mathrm{CH}$ (complete heading).

$\mathrm{T}_{6}=1 / 4$ as $\mathrm{B}+1 / 4$ at $\mathrm{MT}+1 / 4$ at $\mathrm{PI}+1 / 4$ at $\mathrm{F}$ (flowering).

\section{A.8. Panicle length (cm):}

Results presented in Table (11) illustrate that the effect of nitrogen levels on panicle length $(\mathrm{cm})$ was significant in 2011 season. The longest panicles in 2011 season were found with the addition of $220 \mathrm{~kg} \mathrm{~N} / \mathrm{ha}$. While, the shortest panicles in the first season were obtained when $165 \mathrm{~kg} \mathrm{~N} / \mathrm{ha}$ was applied. This might be due to the favorable effect of nitrogen on rice plants and this in turn encouraged the growth of rice plants and subsequently the excersion of panicle. The present findings is in agreement with those obtained by Ebaid (2005 b), Mikhael (2010) and Sheta (2010). 
Abdel-Fattah, A. G. et al.

Table11. Panicle length $(\mathrm{cm})$ and number of primary branches/panicle of hybrid rice as affected by nitrogen levels, times of nitrogen application and their interaction in 2011 and 2012 seasons.

\begin{tabular}{|c|c|c|c|c|}
\hline \multirow{2}{*}{$\begin{array}{c}\text { Nitrogen } \\
\text { levels }\end{array}$} & \multicolumn{2}{|c|}{ Panicle length(cm) } & \multicolumn{2}{|c|}{ No. of primary branches/panicle } \\
\hline & 2011 & 2012 & 2011 & 2012 \\
\hline $165 \mathrm{Kg} / \mathrm{ha}$ & 21.72 b & 21.98 & 10.00 & 10.05 \\
\hline $220 \mathrm{Kg} / \mathrm{ha}$ & $22.14 \mathrm{a}$ & 22.38 & 10.09 & 10.20 \\
\hline F. test & * & NS & N S & N S \\
\hline $\begin{array}{l}\text { Times of } \mathrm{N} \\
\text { application }\end{array}$ & & & & \\
\hline T1 & $21.18 \mathrm{c}$ & $21.25 \mathrm{e}$ & $9.74 \mathrm{~b}$ & $9.79 \mathrm{c}$ \\
\hline T2 & $21.95 \mathrm{~b}$ & $22.31 \mathrm{bc}$ & $10.21 \mathrm{a}$ & $10.24 a b$ \\
\hline T3 & $21.91 \mathrm{~b}$ & $21.96 \mathrm{~cd}$ & $9.86 \mathrm{~b}$ & $9.93 \mathrm{c}$ \\
\hline T4 & 22.44 a & $22.54 \mathrm{ab}$ & $10.29 \mathrm{a}$ & $10.38 \mathrm{a}$ \\
\hline T5 & $21.56 \mathrm{~b}$ & $21.74 \mathrm{~d}$ & $9.85 \mathrm{~b}$ & $9.88 \mathrm{c}$ \\
\hline T6 & $22.51 \mathrm{a}$ & 22.85 a & $10.33 \mathrm{a}$ & 10.46 a \\
\hline F.test & $\star \star$ & $\star \star$ & $\star \star$ & $\star \star *$ \\
\hline NxT & NS & NS & NS & NS \\
\hline
\end{tabular}

${ }^{*},{ }^{* *}$ and $\mathrm{N} . \mathrm{S}$ indicate $\mathrm{P}<0.05, \mathrm{P}<0.01$ and not significant, respectively.

Means designated by the same letter are not significantly different at the $5 \%$ level by DMRT.

$\mathrm{T}_{1}=2 / 3$ as $\mathrm{B}$ (basal) $+1 / 3$ at $\mathrm{PI}$ (panicle initiation).

$T_{2}=1 / 3$ as $B+1 / 3$ at $M T$ (mid-tillering) $+1 / 3$ at $P I$.

$\mathrm{T}_{3}=1 / 2$ as $\mathrm{B}+1 / 4$ at $\mathrm{MT}+1 / 4$ at $\mathrm{PI}$.

$\mathrm{T}_{4}=1 / 4$ as $\mathrm{B}+1 / 4$ at $\mathrm{MT}+1 / 4$ at $\mathrm{PI}+1 / 4$ at $\mathrm{BT}$ (booting).

$\mathrm{T}_{5}=1 / 4$ as $\mathrm{B}+1 / 4$ at $\mathrm{MT}+1 / 4$ at $\mathrm{BT}+1 / 4$ at $\mathrm{CH}$ (complete heading).

$\mathrm{T}_{6}=1 / 4$ as $\mathrm{B}+1 / 4$ at $\mathrm{MT}+1 / 4$ at $\mathrm{PI}+1 / 4$ at $\mathrm{F}$ (flowering).

Data in Table (11) revealed that panicle length $(\mathrm{cm})$ was greatly influenced by times of nitrogen application in both seasons. The sixth treatment $\mathrm{T}_{6}(1 / 4$ as basal $+1 / 4$ at M.T $+1 / 4$ at $\mathrm{P} . \mathrm{I}+1 / 4$ at flowering $)$ gave the longest panicles, without significant differences with the fourth treatment $\mathrm{T}_{4}$ $(1 / 4$ as basal $+1 / 4$ at $\mathrm{MT}+1 / 4$ at $\mathrm{PI}+1 / 4$ at booting). While, the shortest panicles were produced with the first treatment $T_{1}(2 / 3$ as basal $+1 / 3$ at panicle initiation). Application of one-fourth of nitrogen dose at the start of flowering was mainly due to the fact that the role of nitrogen at this growth stage might be speed up the formation of growth regulators such as auxines of hormones which increased the panicle exertion through increasing the internodes elongation located below the panicle. These findings are in congruent with that obtained by Arafat (2007) and El-Kallawy (2008).

The interaction between nitrogen levels and times of nitrogen application had insignificant effect on panicle length $(\mathrm{cm})$ in the two study seasons, (Table 11).

A.9.Number of primary branches/ panicle:

Data was observed that insignificant effect was induced by the nitrogen levels on number of primary branches/ panicle in couple of studied seasons (Table 11).

It was clear from Table 11 that time of nitrogen application affected significantly number of primary branches/panicle in both seasons. The sixth 
treatment $\mathrm{T}_{6}(1 / 4$ as basal $+1 / 4$ at $\mathrm{MT}+1 / 4$ at $\mathrm{PI}+1 / 4$ at flowering $)$ gave the highest number of primary branches/ panicle, without significant differences with the fourth and second treatments $\left(T_{4} \& T_{2}\right)$ in both seasons. While, the first treatment $T_{1}(2 / 3$ as basal $+1 / 3$ at panicle initiation) produced the lowest number of primary branches/panicle, without significant differences with the third a fifth treatments $\left(T_{3} \& T_{5}\right)$ in both seasons. Similar trend was found by El-Kallawy (2008).

The interaction between the nitrogen levels and times of nitrogen application had no significant effect on number of primary branches/panicle in both seasons, (Table 11).

\section{B. Yield and its components:}

\section{B.1. Number of panicles $/ \mathrm{m}^{2}$ :}

The data reported no significant differences were reported among the nitrogen levels on number of panicles $/ \mathrm{m}^{2}$ in both seasons (Table 12).

Concerning to the effect of times of nitrogen application on number of panicles $/ \mathrm{m}^{2}$, data in Table 12 show that the sixth tested treatment $\left(T_{6}\right)$ of nitrogen application had highly significant effect on number of panicles $/ \mathrm{m}^{2}$ in both seasons. The sixth treatment of nitrogen application $T_{6}(1 / 4$ as basal + $1 / 4$ at $\mathrm{MT}+1 / 4$ at $\mathrm{PI}+1 / 4$ at flowering) produced the highest number of panicles $/ \mathrm{m}^{2}$ in the first and second seasons, without significant differences with the fourth and second treatments of nitrogen application $\left(T_{4} \& T_{2}\right)$ in both seasons. On the other hand, the first treatment of nitrogen application $\mathrm{T}_{1}(2 / 3$ as basal $+1 / 3$ at panicle initiation) produced the lowest number of panicles $/ \mathrm{m}^{2}$ in both seasons, respectively, without significant differences with the third or fifth treatment. These results indicated that application of nitrogen consecutively according to plant $\mathrm{N}$-demand at physiological growth stages especially at the beginning of flowering significantly increased panicles $/ \mathrm{m}^{2}$ through reduced mortality percentage and stabilized panicles $/ \mathrm{m}^{2}$ during reproductive stage. The same trend was found by Edwin et al. (2004), Mohammed (2006) and El-Kallawy (2008).

The interaction between nitrogen levels and times of nitrogen application had no significant effect on number of panicles $/ \mathrm{m}^{2}$ in both seasons, (Table 12).

\section{B.2. Number of filled grains/ panicle:}

Data showed that varying nitrogen levels had observable significant effect on number of filled grains/ panicle in both seasons (Table 12). In this concern, the nitrogen level ( $165 \mathrm{~kg} \mathrm{~N} / \mathrm{ha}$ ) produced the higher number of filled grains/ panicle in the two seasons, respectively. While, nitrogen level $(220 \mathrm{~kg}$ $\mathrm{N} / \mathrm{ha}$ ) recorded the lower number of filled grains/panicle in both seasons, respectively. Nitrogen fertilization improved growth and increased the assimilate products and enhanced the source and sink consequently, resulting of more filled grains against unfilled grains/ panicle. The obtained data related to number of filled grains/ panicle completely agreed with those claimed by El-Rewiny et al. (2004), Ebaid (2005b), Salama (2005) and Mikhael(2010). 
Abdel-Fattah, A. G. et al.

With respect to the influence of times of nitrogen application on number of filled grains/panicle, data presented in Table 12 revealed that the different times of nitrogen application varied significantly regarding their effect on this character. Data confirmed the superiority of spilt of nitrogen application into four doses, one of them at flowering stage. The highest number of filled grains/panicle during the first and second seasons, were produced when one-fourth of nitrogen was applied as basal, one- fourth at MT, one-fourth at $\mathrm{PI}$ and one-fourth at flowering was applied. The lowest number of filled grains/panicle in 2011 and 2012 seasons, were produced when two-third of nitrogen as basal and one-third at panicle initiation was applied. Nitrogen application at critical growth stage such maximum tillering stage, panicle initiation and heading stage for hybrid rice showed high effective in improving source parameter and leading to improving grain filling. Similar results were obtained by IRRI (2002), Edwin et al. (2004) and Mohammed (2006).

The interaction between nitrogen level and time of nitrogen application had significant effect on number of filled grains/panicle in the two seasons, Table (12).

Data in Table (13) reveal that the maximum number of filled grains/panicle in the first and second seasons, were recorded under the sixth treatment T6 (1/4 as basal $+1 / 4$ at MT $+1 / 4$ at $\mathrm{PI}+1 / 4$ at flowering ) with $165 \mathrm{~kg} \mathrm{~N} / \mathrm{ha}$ or $220 \mathrm{~kg} \mathrm{~N} / \mathrm{ha}$.

On the other hand, the minimum number of filled grains/ panicle in both seasons, were produced from the fifth treatment T5 ( $1 / 4$ as basal $+1 / 4$ at $\mathrm{MT}+1 / 4$ at BT + 1/4 at complete heading ) fertilized by $220 \mathrm{~kg} \mathrm{~N} / \mathrm{ha}$.

\section{B.3. Number of unfilled grains/ panicle:}

Data related to number of unfilled grains/panicle of hybrid rice as affected by nitrogen level, time of nitrogen application as well as their interaction in 2011 and 2012 seasons are shown in Table (12).

As for nitrogen level effect, increasing $\mathrm{N}$-level significantly increased number of unfilled grains/panicle in both seasons. The higher number of unfilled grains/panicle in the two seasons, were produced when $220 \mathrm{~kg} \mathrm{~N} / \mathrm{ha}$ was applied, while the lower number of unfilled grains/panicle were obtained from $165 \mathrm{~kg} \mathrm{~N} / \mathrm{ha}$. The higher increases in number of unfilled grains of rice plants maintained at the higher level of nitrogen may be attributed to the shortage of carbohydrate supplied per grain which is directly caused by high number of grains produced by heavy nitrogen fertilization. Similar trend was obtained by Salama (2005).

For the effect of times of nitrogen application on number of unfilled grains /panicle, the data listed in Table (12) show that number of unfilled grains/panicle was significantly influenced by times of nitrogen application in the two seasons. It was found that nitrogen splitting $(1 / 4$ as basal $+1 / 4$ at MT $+1 / 4$ at BT $+1 / 4$ at complete heading) significantly increased number of unfilled grains/panicle and gave the maximum number of unfilled grains/panicle. On the other hand, the minimum number of unfilled grains/panicle, in both seasons, were produced with nitrogen splitting as $1 / 4$ as basal $+1 / 4$ at $\mathrm{MT}+1 / 4$ at $\mathrm{PI}+1 / 4$ at booting. These data are in harmony with those reported by Edwin et al. (2004). 
The interaction between the two factors under study significantly affected number of unfilled grains/panicle in the second season, (Table 12).

Table12.Number of panicles $/ \mathrm{m}^{2}$, Number of filled grains/panicle and Number of unfilled grains/panicle of hybrid rice as affected by nitrogen levels, times of nitrogen application and their interaction in 2011 and 2012 seasons

\begin{tabular}{|c|c|c|c|c|c|c|}
\hline \multirow{2}{*}{\begin{tabular}{|l|} 
characters \\
treatments
\end{tabular}} & \multicolumn{2}{|c|}{ Number of panicles $/ \mathrm{m}^{2}$} & \multicolumn{2}{|c|}{$\begin{array}{l}\text { Number of filled } \\
\text { grains/panicle }\end{array}$} & \multicolumn{2}{|c|}{$\begin{array}{l}\text { Number of unfilled } \\
\text { grains/panicle }\end{array}$} \\
\hline & 2011 & 2012 & 2011 & 2012 & 2011 & 2012 \\
\hline $165 \mathrm{Kg} / \mathrm{ha}$ & 578.0 & 593.00 & 135.17a & $137.79 a$ & $4.03 \mathrm{~b}$ & $4.65 \mathrm{~b}$ \\
\hline $220 \mathrm{Kg} / \mathrm{ha}$ & 590.0 & 608.00 & 129.94b & 133.00b & $5.65 \mathrm{a}$ & $6.43 \mathrm{a}$ \\
\hline F. test & N S & N S & $\star \star$ & $\star$ & ** & *x \\
\hline \multicolumn{7}{|l|}{$\begin{array}{l}\text { Times of } \mathrm{N} \\
\text { application }\end{array}$} \\
\hline T1 & 568.0b & $584.0 \mathrm{c}$ & $122.79 f$ & $125.31 \mathrm{f}$ & $5.34 \mathrm{~b}$ & $6.09 \mathrm{~b}$ \\
\hline T2 & 580.0ab & 602.0ab & $131.48 \mathrm{c}$ & $134.86 c$ & $4.48 \mathrm{~cd}$ & $5.21 \mathrm{~d}$ \\
\hline T3 & $576.0 \mathrm{~b}$ & $592.0 b c$ & 129.81d & $131.36 d$ & $4.71 \mathrm{c}$ & $5.63 \mathrm{c}$ \\
\hline T4 & $602.0 \mathrm{a}$ & 616.0ab & 138.36b & 143.81b & $3.96 \mathrm{e}$ & $4.45 \mathrm{f}$ \\
\hline T5 & $570.0 \mathrm{~b}$ & $588.0 \mathrm{bc}$ & $124.76 \mathrm{e}$ & $127.65 \mathrm{e}$ & $6.10 \mathrm{a}$ & $7.08 \mathrm{a}$ \\
\hline T6 & $606.0 \mathrm{a}$ & $622.0 \mathrm{a}$ & $140.18 a$ & $146.54 a$ & $4.28 \mathrm{~d}$ & $4.79 \mathrm{e}$ \\
\hline F.test & * & * & ** & ** & $\star \star$ & ** \\
\hline NxT & NS & NS & * & * & NS & ** \\
\hline
\end{tabular}

${ }^{*},{ }^{* *}$ and N.S indicate $P<0.05, P<0.01$ and not significant, respectively.

Means designated by the same letter are not significantly different at the $5 \%$ level by DMRT.

$\mathrm{T}_{1}=2 / 3$ as $\mathrm{B}$ (basal) $+1 / 3$ at $\mathrm{PI}$ (panicle initiation).

$\mathrm{T}_{2}=1 / 3$ as $\mathrm{B}+1 / 3$ at $\mathrm{MT}$ (mid-tillering) $+1 / 3$ at $\mathrm{PI}$.

$\mathrm{T}_{3}=1 / 2$ as $\mathrm{B}+1 / 4$ at $\mathrm{MT}+1 / 4$ at $\mathrm{PI}$.

$T_{4}=1 / 4$ as $B+1 / 4$ at $M T+1 / 4$ at $P I+1 / 4$ at $B T$ (booting).

$\mathrm{T}_{5}=1 / 4$ as $\mathrm{B}+1 / 4$ at $\mathrm{MT}+1 / 4$ at $\mathrm{BT}+1 / 4$ at $\mathrm{CH}$ (complete heading).

$\mathrm{T}_{6}=1 / 4$ as $\mathrm{B}+1 / 4$ at $\mathrm{MT}+1 / 4$ at $\mathrm{PI}+1 / 4$ at $\mathrm{F}$ (flowering).

Data presented in Table (13) show clearly that the highest number of unfilled grains/panicle in 2012 season was produced from the fifth treatment $\mathrm{T}_{5}(1 / 4$ as basal $+1 / 4$ at $\mathrm{MT}+1 / 4$ at $\mathrm{BT}+1 / 4$ at complete heading ) and fertilized with $165 \mathrm{~kg} \mathrm{~N} / \mathrm{ha}$. Meanwhile, the lowest number of unfilled grains/panicle in the second season was produced with sixth treatment of nitrogen application $(1 / 4$ as basal $+1 / 4$ at $\mathrm{MT}+1 / 4$ at $\mathrm{PI}+1 / 4$ at flowering) was applied and fertilized with $220 \mathrm{~kg} \mathrm{~N} / \mathrm{ha}$.

B.4. Panicle weight (g):

From Table 14, the results revealed that a insignificant effect resulted from the nitrogen levels on panicle weight in both seasons. These data are in a harmony with those reported by Abd El-Salam (2003). 
Abdel-Fattah, A. G. et al.

Table13. Effect of the interaction between nitrogen levels and times of nitrogen application on number of filled grains/panicle and Number of unfilled grains/panicle in 2011 and 2012 seasons.

\begin{tabular}{|c|c|c|c|c|c|c|}
\hline \multirow{2}{*}{$\begin{array}{c}\text { Times of } \mathbf{N}- \\
\text { application }\end{array}$} & \multicolumn{4}{|c|}{ Number of filled grains/panicle } & \multicolumn{2}{c|}{$\begin{array}{c}\text { Number of unfilled } \\
\text { grains/panicle }\end{array}$} \\
\cline { 2 - 7 } & \multicolumn{3}{|c|}{ 2011 season } & \multicolumn{2}{c|}{$\mathbf{2 1 1 2 s e a s o n s}$} & \multicolumn{2}{c|}{ 2012 season } \\
\cline { 2 - 7 } & \multicolumn{4}{|c|}{ Nitrogen levels (kg N/ha) } & \multicolumn{2}{c|}{ Nitrogen levels(kg/ha) } \\
\cline { 2 - 7 } & $\mathbf{1 6 5}$ & $\mathbf{2 2 0}$ & $\mathbf{1 6 5}$ & $\mathbf{2 2 0}$ & $\mathbf{1 6 5}$ & $\mathbf{2 2 0}$ \\
\hline $\mathrm{T}_{1}$ & $124.90 \mathrm{~g}$ & $124.58 \mathrm{~g}$ & $126.55 \mathrm{f}$ & $126.45 \mathrm{f}$ & $7.03 \mathrm{~b}$ & $5.15 \mathrm{f}$ \\
\hline $\mathrm{T}_{2}$ & $133.53 \mathrm{~d}$ & $129.43 \mathrm{e}$ & $132.69 \mathrm{~d}$ & $137.25 \mathrm{c}$ & $6.18 \mathrm{~cd}$ & $4.25 \mathrm{hi}$ \\
\hline $\mathrm{T}_{3}$ & $131.78 \mathrm{~d}$ & $127.85 \mathrm{ef}$ & $132.35 \mathrm{~d}$ & $130.38 \mathrm{de}$ & $6.60 \mathrm{c}$ & $4.65 \mathrm{gh}$ \\
\hline $\mathrm{T}_{4}$ & $139.45 \mathrm{~b}$ & $137.28 \mathrm{c}$ & $143.93 \mathrm{~b}$ & $143.70 \mathrm{~b}$ & $4.83 \mathrm{fg}$ & $4.08 \mathrm{i}$ \\
\hline $\mathrm{T}_{5}$ & $126.30 \mathrm{fg}$ & $120.23 \mathrm{~h}$ & $122.78 \mathrm{~g}$ & $128.75 \mathrm{ef}$ & $8.30 \mathrm{a}$ & $5.85 \mathrm{de}$ \\
\hline $\mathrm{T}_{6}$ & $143.05 \mathrm{a}$ & $137.30 \mathrm{c}$ & $144.88 \mathrm{~b}$ & $148.20 \mathrm{a}$ & $5.68 \mathrm{e}$ & $3.80 \mathrm{j}$ \\
\hline
\end{tabular}

${ }^{*}$, ${ }^{*}$ and N.S indicate $P<0.05, P<0.01$ and not significant, respectively.

Means designated by the same letter are not significantly different at the $5 \%$ level by DMRT.

$T_{1}=2 / 3$ as $B$ (basal) $+1 / 3$ at $\mathrm{PI}$ (panicle initiation).

$T_{2}=1 / 3$ as $B+1 / 3$ at $M T$ (mid-tillering) $+1 / 3$ at $P$.

$\mathrm{T}_{3}=1 / 2$ as $\mathrm{B}+1 / 4$ at $M T+1 / 4$ at $\mathrm{PI}$.

$T_{4}=1 / 4$ as $B+1 / 4$ at $M T+1 / 4$ at $P I+1 / 4$ at $B T$ (booting).

$T_{5}=1 / 4$ as $B+1 / 4$ at $M T+1 / 4$ at $B T+1 / 4$ at $\mathrm{CH}$ (complete heading).

$\mathrm{T}_{6}=1 / 4$ as $\mathrm{B}+1 / 4$ at $\mathrm{MT}+1 / 4$ at $\mathrm{PI}+1 / 4$ at $\mathrm{F}$ (flowering).

With respect to impact of times of nitrogen application on panicle weight, it was found that panicle weight was significantly affected by times of nitrogen application in both seasons. The heaviest panicles were recorded with the sixth treatment of nitrogen application $(1 / 4$ as basal $+1 / 4$ at $M . T+1 / 4$ at P.I+1/4 at flowering) without significant differences with the fourth treatment of nitrogen application. Meanwhile, the lightest panicles were obtained with the first treatment of nitrogen application $(2 / 3$ as basal+ $1 / 3$ at panicle initiation). It is obvious that splitting into four equal doses, one of them at flowering stage improved grain filling processes that could be attributed to delaying of leaf senescence and enhancing photosynthetic rate. This, in turn, improved store assimilates and dries matter partitioning from stem to rice grains. This leads to that improving of grain filling resulted in heavy grain in the terms of heavy panicle weight. The present findings are in agreement with those obtained by IRRI (2000), Mohammed (2006), Arafat (2007) and ElKallawy (2008).

The interaction between nitrogen levels and times of nitrogen application had no significant effect on panicle weight in both seasons (Table 14). 
Table14: Panicle weight $(\mathrm{g})$ and 1000-grain weight $(\mathrm{g})$ of hybrid rice as affected by nitrogen levels, times of nitrogen application and their interaction in 2011 and 2012 seasons.

\begin{tabular}{|c|c|c|c|c|}
\hline \multirow{2}{*}{ characters } & \multicolumn{2}{|c|}{ Panicle weight (g) } & \multicolumn{2}{c|}{ 1000-grain weight } \\
(g)
\end{tabular}

*, ** and N.S indicate $P<0.05, P<0.01$ and not significant, respectively.

Means designated by the same letter are not significantly different at the $5 \%$ level by DMRT.

$\mathrm{T}_{1}=2 / 3$ as $\mathrm{B}$ (basal) $+1 / 3$ at $\mathrm{PI}$ (panicle initiation).

$T_{2}=1 / 3$ as $B+1 / 3$ at $M T$ (mid-tillering) $+1 / 3$ at $P I$.

$\mathrm{T}_{3}=1 / 2$ as $\mathrm{B}+1 / 4$ at $M T+1 / 4$ at $\mathrm{PI}$.

$\mathrm{T}_{4}=1 / 4$ as $\mathrm{B}+1 / 4$ at $\mathrm{MT}+1 / 4$ at $\mathrm{PI}+1 / 4$ at $\mathrm{BT}$ (booting).

$T_{5}=1 / 4$ as $B+1 / 4$ at $M T+1 / 4$ at $B T+1 / 4$ at $C H$ (complete heading).

$\mathrm{T}_{6}=1 / 4$ as $\mathrm{B}+1 / 4$ at $\mathrm{MT}+1 / 4$ at $\mathrm{PI}+1 / 4$ at $\mathrm{F}$ (flowering).

\section{B.5. 1000-Grain weight $(\mathrm{g})$ :}

Concerning to the effect of nitrogen levels on 1000-grain weight, the results presented in Table 14 clarified that the nitrogen levels didn't exert any significant effect on 1000-grain weight in the first and second seasons of study.

Data obtained during both seasons, showed that varying the times of nitrogen application resulted in significant differences in 1000-grain weight (Table 14). The heaviest 1000-grain weights, in both seasons, were produced with the sixth treatment $\mathrm{T} 6(1 / 4$ as basal $+1 / 4$ at $\mathrm{MT}+1 / 4$ at $\mathrm{PI}+1 / 4$ at flowering) without significant differences with the fourth, third and second treatments $(\mathrm{T} 4, \mathrm{~T} 3$ \&T2).Whereas, the lightest 1000-grain weight $(24.87$ \& $24.92 \mathrm{~g}$ ) were obtained from the first treatment $\mathrm{T} 1$ ( $2 / 3$ as basal $+1 / 3$ at panicle initiation) was applied without significant differences with the fifth treatment T5 ( $1 / 4$ as basal $+1 / 4$ at MT $+1 / 4$ at BT $+1 / 4$ at complete heading). Similar trend was obtained by IRRI (2000) and El-Kallawy (2008).

The interaction between the two experimental factors under study had insignificant effect on 1000-grain weight in the two seasons (Table 14). 


\section{B.6. Grain yield ( $t / h a)$ :}

As a matter of fact, one of main important objectives for this study is improve grain yield with optimum and economic level of nitrogen. The results in Table (15) showed that nitrogen application had significant effect on grain yield in both seasons. The nitrogen level $(165 \mathrm{~kg} \mathrm{~N} / \mathrm{ha}$ ) was optimum level to produce the highest grain yield in both seasons. The highest values of grain yield (10.47 \& $10.62 \mathrm{t} / \mathrm{ha}$ ) in 2011 and 2012 seasons, respectively, were recorded when $165 \mathrm{~kg} \mathrm{~N} / \mathrm{ha}$ was applied. Moreover, the lowest values of grain yield (10.26 \& $10.41 \mathrm{t} / \mathrm{ha})$ in the first and second seasons, respectively, were produced when the highest nitrogen level $220 \mathrm{~kg} \mathrm{~N} / \mathrm{ha}$ was used. The favorable effect of nitrogen on yield might be due to its action for improving growth as a source and sink characters and ultimately the grain yield of rice. These results are in harmony with those reported by Ebaid (2005 b), Salama (2005), Gewally (2006), Gorgy (2010), Mikhael (2010) and Fukushima et al. (2011).

With respect to the effect of nitrogen application times on grain yield, data listed in Table 15, revealed that there is a significant effect for times of nitrogen application on grain yield in the two study seasons. The results indicate that more nitrogen splitting one of them added at heading stage is more favorable for increasing grain yield of hybrid rice. The maximum grain yield, in both seasons, was produced with the sixth treatment of nitrogen application ( $1 / 4$ as basal $+1 / 4$ at $\mathrm{MT}+1 / 4$ at $\mathrm{PI}+1 / 4$ at flowering) without significant differences with the fourth treatment in the two seasons. Meanwhile, the first treatment of nitrogen application (two-third as basal + one-third at panicle initiation) gave the minimum grain yield without significant differences with the fifth treatment of nitrogen application (1/4 as basal $+1 / 4$ at $M T+1 / 4$ at BT $+1 / 4$ at complete heading). Nitrogen application at late growth stages delayed leaf aging and increased activity of root and the three active leaves during grain filling rate and reduced the sterility percentage which greatly increased grain yield. These results are in pertinence with those reported by IRRI (2000), Edwin et al. (2004), Mohammed (2006), Arafat (2007), El-Kallawy (2008) and Sathiya and Ramesh (2009).

The interaction between nitrogen levels and times of nitrogen application had no significant effect on grain yield in both seasons, (Table 15).

\section{B.7. Straw yield (t/ha):}

Data in Table 15 clarified that the straw yield (t/ha) significantly increased by increasing nitrogen level up to $220 \mathrm{~kg} \mathrm{~N} / \mathrm{ha}$ in both seasons. The higher values of straw yield was produced from application of nitrogen fertilizer at $220 \mathrm{~kg} \mathrm{~N} / \mathrm{ha}$. On the other hand, the lower value of straw yield was obtained when the lower level of nitrogen $(165 \mathrm{~kg} \mathrm{~N} / \mathrm{ha}$ ) was applied in both seasons. The nitrogen application improved growth characters; .e. dry matter, leaf area index, plant height and tillers formation, which, increased the straw yield. The obtained data are in agreement with those reported by Ebaid (2005b), Arafat (2007), Badawi (2008), Gorgy (2010) and Mikhael (2010).

With respect to the effect of times of nitrogen application on straw yield (Table 15), the results clearly showed that splitting nitrogen application a significant effect on straw yield in both seasons. The highest values of straw 
yield were produced from the first treatment $T_{1}(2 / 3$ as basal $+1 / 3$ at panicle initiation) without significant differences with the treatments $\left(T_{2}, T_{3} \& T_{5}\right)$ in both seasons. Meanwhile, the lowest values of straw yield was obtained with the sixth treatment $\mathrm{T}_{6}(1 / 4$ as basal $+1 / 4$ at $\mathrm{MT}+1 / 4$ at $\mathrm{PI}+1 / 4$ at flowering $)$ without any significant differences with the fourth treatment $\mathrm{T}_{4}(1 / 4$ as basal + $1 / 4$ at $\mathrm{MT}+1 / 4$ at $\mathrm{PI}+1 / 4$ at booting) in the two seasons. These findings are in harmony with those reported by Ebaid and El-Mowafi (2005), Arafat (2007) and El-Kallawy (2008).

The interaction between the two factors under study (nitrogen levels and times of nitrogen application) had no significant effect on straw yield in the two seasons (Table 15).

Table15. Grain yield ( $t / h a)$, Straw yield ( $t / h a)$ and Harvest index of hybrid rice as affected by nitrogen levels, times of nitrogen application and their interaction in 2011and 2012seasons

\begin{tabular}{|c|c|c|c|c|c|c|}
\hline \multirow{2}{*}{\begin{tabular}{|l|} 
characters \\
treatments \\
\end{tabular}} & \multicolumn{2}{|c|}{ Grain yield (t/ha) } & \multicolumn{2}{|c|}{ Straw yield (t/ha) } & \multicolumn{2}{|c|}{ Harvest index (HI) } \\
\hline & 2011 & 2011 & 2011 & 2012 & 2011 & 2012 \\
\hline 165Kg/ha & $10.47 a$ & $10.62 a$ & $15.06 \mathrm{~b}$ & $15.16 \mathrm{~b}$ & 41.00 & $41.22 \mathrm{a}$ \\
\hline $220 \mathrm{Kg} / \mathrm{ha}$ & $10.26 \mathrm{~b}$ & $10.41 b$ & $15.70 \mathrm{a}$ & $15.81 \mathrm{a}$ & 39.52 & $39.69 b$ \\
\hline F. test & * & * & ** & ** & ** & $\star \star$ \\
\hline \multicolumn{7}{|l|}{$\begin{array}{l}\text { Times of } \mathrm{N} \\
\text { application }\end{array}$} \\
\hline $\mathrm{T} 1$ & $9.98 \mathrm{~d}$ & $10.05 d$ & $15.52 \mathrm{a}$ & $15.65 \mathrm{a}$ & $39.15 c$ & $39.08 \mathrm{e}$ \\
\hline T2 & $10.40 \mathrm{~b}$ & $10.59 b$ & $15.48 \mathrm{a}$ & 15.59ab & 40.19 & $40.52 c$ \\
\hline T3 & $10.18 \mathrm{c}$ & $10.33 \mathrm{c}$ & $15.49 \mathrm{a}$ & $15.57 a b$ & $39.66 c$ & $39.87 d$ \\
\hline $\mathrm{T} 4$ & $10.75 \mathrm{a}$ & $10.91 a$ & $15.19 \mathrm{~b}$ & $15.33 \mathrm{c}$ & $41.44 a$ & $41.55 b$ \\
\hline T5 & $10.01 \mathrm{~cd}$ & $10.15 d$ & $15.46 \mathrm{a}$ & $15.56 \mathrm{~b}$ & $39.30 c$ & $39.51 d$ \\
\hline T6 & $10.88 \mathrm{a}$ & $11.06 a$ & $15.15 b$ & $15.11 \mathrm{c}$ & $41.80 \mathrm{a}$ & $42.25 a$ \\
\hline F.test & $\star *$ & ** & * & ** & $\star \star$ & $\star \star *$ \\
\hline NxT & NS & NS & NS & NS & NS & NS \\
\hline
\end{tabular}

*, ** and N.S indicate $P<0.05, P<0.01$ and not significant, respectively.

Means designated by the same letter are not significantly different at the $5 \%$ level by DMRT.

$T_{1}=2 / 3$ as $B$ (basal) $+1 / 3$ at $\mathrm{PI}$ (panicle initiation).

$\mathrm{T}_{2}=1 / 3$ as $\mathrm{B}+1 / 3$ at $\mathrm{MT}$ (mid-tillering) $+1 / 3$ at $\mathrm{PI}$.

$\mathrm{T}_{3}=1 / 2$ as $\mathrm{B}+1 / 4$ at $\mathrm{MT}+1 / 4$ at $\mathrm{PI}$.

$\mathrm{T}_{4}=1 / 4$ as $\mathrm{B}+1 / 4$ at $\mathrm{MT}+1 / 4$ at $\mathrm{PI}+1 / 4$ at $\mathrm{BT}$ (booting).

$T_{5}=1 / 4$ as $B+1 / 4$ at $M T+1 / 4$ at $B T+1 / 4$ at $\mathrm{CH}$ (complete heading).

$\mathrm{T}_{6}=1 / 4$ as $\mathrm{B}+1 / 4$ at $\mathrm{MT}+1 / 4$ at $\mathrm{PI}+1 / 4$ at $\mathrm{F}$ (flowering).

\section{B.8. Harvest index $(\mathrm{HI})$ :}

Respecting the effect of nitrogen fertilizer levels on harvest index, the results of harvest index in Table 15 clarified that the nitrogen fertilizer levels showed significant effect on harvest index in the first and second seasons. However, increasing nitrogen fertilizer level up to $220 \mathrm{~kg} \mathrm{~N} / \mathrm{ha}$ significantly decreased harvest index. The higher value of harvest index was produced when $165 \mathrm{~kg} \mathrm{~N} / \mathrm{ha}$ was used. While, the lower value of harvest index was obtained when $220 \mathrm{~kg} \mathrm{~N} / \mathrm{ha}$ was applied. The reduction of harvest index value 
with high nitrogen fertilizer level could be mainly due to the reduction in grain yield. These results are in accordance with those of Ebaid (2005 b), Arafat (2007), Rahman et al. (2007), Baba et al. (2010), Mikhael (2010) and Sheta (2010).

According to the analysis of variance, data show that there were significant differences among the six treatments of nitrogen application regarding the harvest index in both seasons, (Table 15). The highest value of harvest index was produced by $T_{6}$ without a significant difference with $T_{4}$ in the first season. While, the lower value of harvest index was produced by using $T_{1}$ without a significant differences with $T_{3} \& T_{5}$ in 2011 season. These results might be due to the effect of the last premium dose of nitrogen applied at flowering which takes, its effectiveness in physiological and nutritional improvement of rice plants which resulted in better grain yield and ultimately increased harvest index. Similar trend was obtained by Edwin et al. (2004), Mohammed (2006), Arafat (2007) and El-Kallawy (2008).

The interaction between nitrogen levels and times of nitrogen application had insignificant effect on harvest index in both study seasons (Table 15).

\section{REFERENCES}

Abd El-Salam, R.M. (2003). Effect of some cultural treatments on rice yield and its components. M.Sc. Thesis, Fac of Agric., Cairo Univ., Egypt.

Arafat, E. (2007). Effect of some agronomic practices on hybrid rice. M.Sc. Thesis, Agron. Dept., Fac. Agric., Kafr El-Sheikh Univ., Egypt.

Baba, M.H.; S.S. Hussain; M.A. Wani and F.A. Misgar (2010). Response of rice ( Oryza sativa, L.) to levels of nitrogen and bio-fertilizers. Research Journal of Agricultural Science, 1(3): 237-241.

Badawi, Shimaa A.B. (2008). Effect of some cultural practices on the productivity of hybrid rice. Ph.D. Thesis, Agron. Dept., Fac. of Agric., Kafr El-Sheikh Univ., Egypt.

Black, C.A.; D.D Evan; L.E. Ensinger; J.L. White and F.E. Clark (1965). Methods of soil analysis (chemical and microbiology properities, part 2). Amer. Soc. of Agron. Inc., Publisher Madison, Wisconsin, USA 1965.

Chang J.; C. Cougui; C. Mingli; Y. Baazhong and Z. Jing (2008). Effect of different nitrogen nutrition and soil water potential on physiological parameters and yield of hybrid rice. Plant Nutrition and Fertilizer Sci., 14(2): 199-206.

Chau, L.M. and k.L. Heong (2005). Effect of organic fertilizers on insect pest and diseases of rice. Omnoric, 13: 26-33.

Dalling, M. J. (1985). The physiological basis of nitrogen redistribution during filling in cereals. P:55-71.In: J.E. Harper et al. (ed.) Exploitation of physiological and genetic variability to enhance crop productivity. American Society of Plant Physiologists, Rockville, MD.

Duncan, D.B. (1955). Multiple Range and Multiple F.Test. Biometrics. 1: 1-42. 
Ebaid, R.A. and S.A. Ghanem (2001). Effect of nitrogenous and potash fertilizers on the productivity of Sakha 101 rice cultivar. J. Agric. Sci. Mansoura Univ., 26(4): 1833-1840.

Ebaid, R.A. (2005a). Performance of broadcast seeded rice Sakha 104 under different nitrogen levels and Zinc methods of application. Egypt. J. Agric. Res., 83(5B): 333-345.

Ebaid, R.A. (2005b). Productivity of Giza 182 rice cultivar as affected by seed rates and nitrogen levels under drill-seeding method. Egypt. J. Agric. Res., 83(5B): 347-358.

Ebaid, R. and H. El-Mowafi (2005). Effect of split applied nitrogen on the productivity of two rice hybrids and Sakha 104 rice cultivar. J. Agric. Res., Tanta Univ., 31(4): 760-776.

Edwin, L. and P. Anal (2008). Effect of irrigation regimes and nitrogen management practices on uptake of nutrients and grain yield in hybrid rice (Oryza sativa L.). Environment and Ecology, 26(3): 1146-1148.

Edwin L.; J. Krishnarajan and M. Premsekhar (2004). Irrigation and nitrogen application schedules for hybrid "ADTRH 1" rice ( Oryza sativa L.) in Tamil Nadu.Indian Journal of Agronomy,49 (11): 37-39.

El-Kallawy, W. (2008). Effect of methods and time of application of different nitrogenous sources on the productivity of hybrid rice. Ph.D. Thesis Agron. Dept., Fac. of Agric., Kafr El-Sheikh. Univ., Egypt.

El-Keredy, M.S.; A.G. Abd El-Hafez; M.M. El-Wehishy; I. El-Degwy and Z. Tan (2004). Hybrid rice as affected by transplanting spacing and nitrogen fertilization. The international conference on Advanced Rice Research. Alexandria, Egypt, 21-23 September.

El-Keredy, M.; M. El-Weheishy; I. El-Degwy; X. Tan and C. Lijuan (2007). Combining ability of some hybrid rice varieties with Chiness-bred cytoplasmic mail sterile lines. J. Agric. Res., Kafr El-Sheikh Univ., 34(1): 11-22.

El-Rewiny, I.M.O. (1996). Effect of some cultural practices on rice. M.Sc. Thesis Fac. of Agric., Minufiya Univ., Egypt.

El-Rewiny, I.M.; S.A. Ghanem and T.F. Metwally (2004). Response of number rice seedling per hill to nitrogen fertilization. The International Conference on Advanced Rice Research. Alexandria, Egypt, 21-23 September.

Fukushima, A.; H. Shiratsuchi; H. Yamaguchi and A. Fukuda (2011). Effect of nitrogen application and planting density on morphological traits, dry matter production and yield of large grain type rice variety Bekoaba and strategies for super high-yielding rice in the Tohoku Region of Japan. Plant Prod. Sci., 14 (1): 56-63.

Gewally, E.E.A. (2006). Behavior of some nutrient in rice soils under different irrigation intervals.Ph.D.Thesis, Fac.ofAgric., Mansoura Univ., Egypt.

Gorgy, R. N. (2010). Effect of transplanting spacings and nitrogen levels on growth, yield and nitrogen use efficiency of some promising rice varieties. J. Agric. Res. Kafr El-Sheikh Univ., 36(2) 123-146.

Gomez K. N. and A. A. Gomez (1984). Statistical Procedures of Agricultural Research. John Wiley and Sons. Inc., New York, U.S.A. 
Huizha C.; Z. Defeng; L. Qing and Z. Ping (2008). Effect of nitrogen levels in spike stage on differentiation and degeneration of branches and spikelet of hybrid rice cultivar Liang You Peijiu. Agric. Sci. in China, 6(3): 265-274.

IRRI, (International Rice Research Institute) (2000). Program report for 1999: Los Banos (Philippines). International Rice Research Institute, 175 P.

Districts of Tamil Nadu. Asian J. of Plant Sci., 4(6): 574-576.

Kabaki, N. (1993). Growth and yield of Japonica-Indica hybrid rice. Japan Agricultural Research, (27): 88:94.

$\mathrm{Li}$, Z.B. (1981). Biological basis of heterosis utilization in rice plant. In: Research and Practice of hybrid rice. Beijing : Agricultural Science and Technology Press.(3) P: 186-287.

Mae, T. (1997). Physiological nitrogen efficiency in rice: Nitrogen utilization, photosynthesis, and yield potential. Plant and Soil, (196):201-210.

Mikhael, B. (2010). Fertilizer requirements for hybrid rice. Ph.D. Thesis, Agron. Dept., Fac. of Agric., Kafr El-Sheikh. Univ., Egypt.

Mohammed, M.(2006). Effect of some agricultural treatments on yield of hybrid rice. M.Sc. Thesis, Agron. Dept., Fac. Agric., Al- Azhar Univ., Egypt.

Nakano, H.; H. Ikuo; K. Sato and S. Morita (2011). Early planting and early nitrogen application increase stem total digestible nutrient concentration and yield of forage rice in South western Japan. Plant Prod. Sci., 14(2): 169-176.

Petroudi,R.E.; G. Noormohammadi; M.J. Mirhadi; H. Madani; H.R. Mobasser (2011). Effect of nitrogen fertilization and rice harvest height on agromic yield indices of ratoon rice-berseem clover intercropping system. Australian Journal of Crop Science, 5(5): 566-574.

Rahman, M.; M. Ali; M. Ali and M. Khatun (2007). Effect of different levels of nitrogen on growth and yield of transplant aman rice $\mathrm{Cv}$ BRRI dhan 32 International J. of Sustainable Crop Production, 2(1): 28-34.

Salama, A.A.S. (2005). Effect of some cultural practices on rice crop. M.Sc. Thesis, Fac. of Agric., Kafr El-Sheikh, Tanta Univ., Egypt.

Sarwar,M.( 2011).Effect of zinc fertilizer a application on the incidence of rice stem borers(Scirpophaga species)(Lepidoptera:Pyralidae) in rice(Oryza sativa L.)Crop. Journal of Cereals and Oilseeds,2(5):61-65.

Sarwar,M.( 2012). Study on the non aromatic rice (Oryza sativa L.) varieties resistance to rice stem borers(Lepidoptera :Pyralidae) and yield factors. International Journal of Agronomy and plant production,3(5):159-163.

Sathiya, K. and T. Ramesh (2009). Effect of split application of nitrogen on growth and yield of aerobic rice. Asian J. EXP. Sci., 23(1): 303-306.

Sherif, M. R . (2002). Insect pests. In: Rice in Egypt (T. Castello cd), Rice Research and Training Center, Ministry of Agriculture and Land Reclamation.

Sheta, I.A.A., (2010). Effect of planting methods and nitrogen levels on the productivity of some hybrids and inbred rice cultivars. M.Sc. Thesis Agron. Dept., Fac Agric., Kafr El-Sheikh Univ., Egypt. 
Song, X.; W. Agata and Y. Kawamitsu (1990). Studies on dry matter production of $\mathrm{F} 1$ hybrid rice in China. II Characteristics of grain production. Japan Journal of Crop Science, 59(1): 29:33.

Thakur, R.B. (1993). Performance of summer rice (Oryza sativa L.) to varying levels of nitrogen. Indian J. of Agron., 38(2): 187-190.

Virmani, S.S.(1996). Hybrid rice. Advanced in agronomy,(57):377-462.

Yamauchi, M. (1994). Physiological bases of higher yield potential in $F_{1}$ hybrids. In: Virmani, SS, editor. Hybrid rice technology. New developments and future prospects, Manila (Philippines): International Rice Research Institute, 13(5): 71-80.

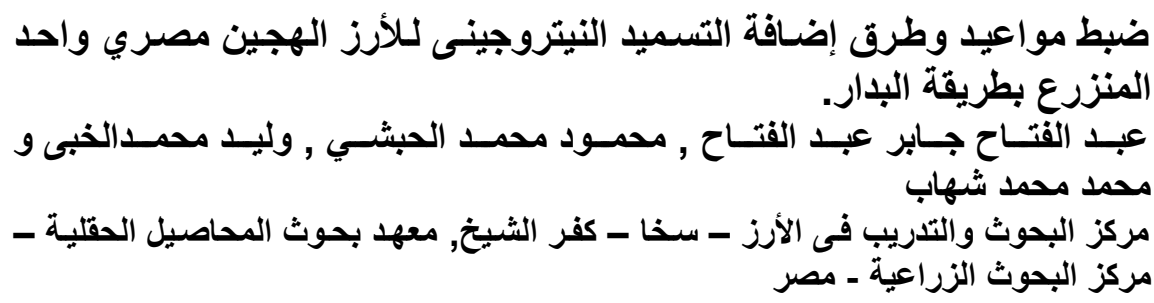

أجريت تجربتان حقليتان بمزر عة مركز البحوث و التدريب في الأرز بسخا_ كفر الثيخ

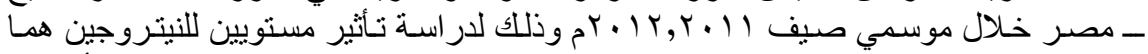

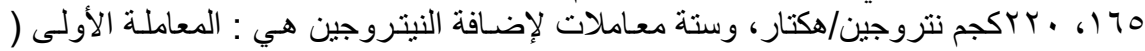

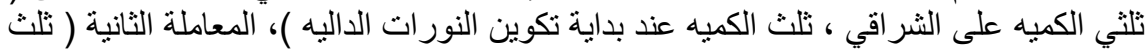

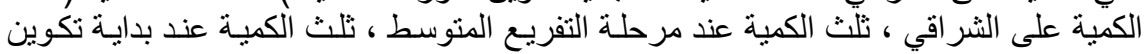

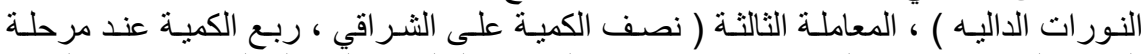

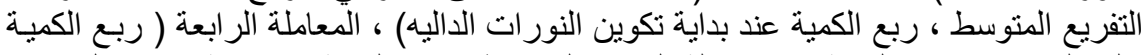

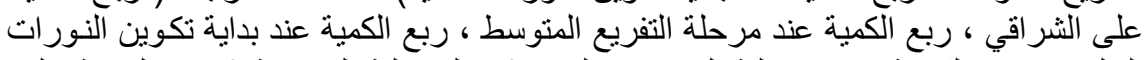

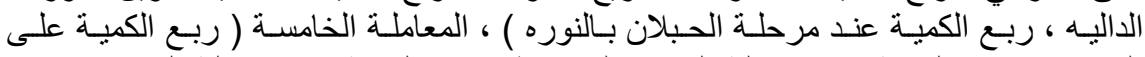

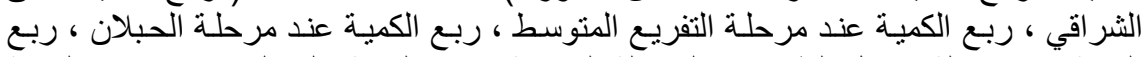

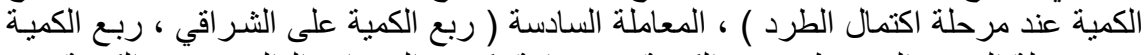

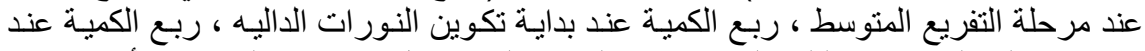

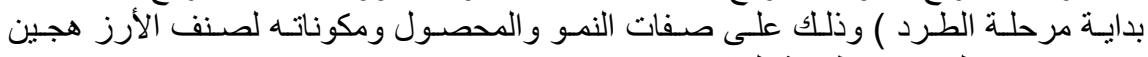
مصري واحد المنزر ع بطريقة البدار.

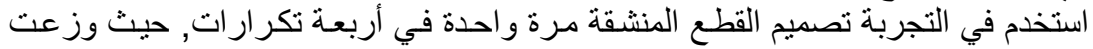
مستويات النيتروجين في القطع الرئيسية, بينما وزعت معاملات إضـافة النيتروجين في القطع التع

$$
\text { أـ صفات النمو:- والتفات التي تم در استها كالأتي:- }
$$

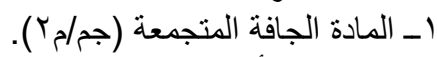

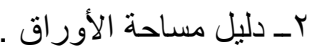

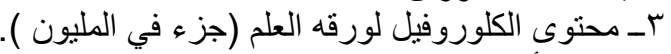

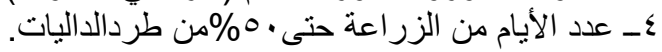

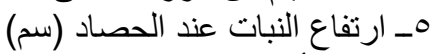

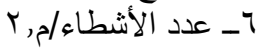

ץ_ طول النوره الدالية (سم) . 
Abdel-Fattah, A. G. et al.

1_ــ النسبة المئوية للإصابة بالثاقبات.

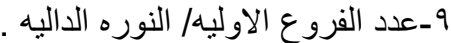

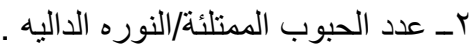

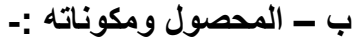

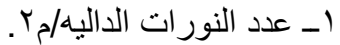

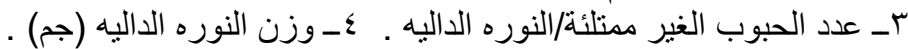

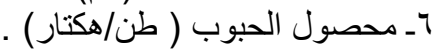

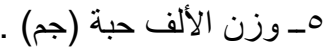

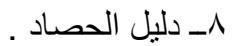

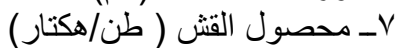

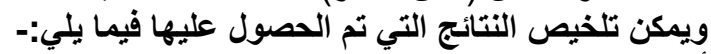

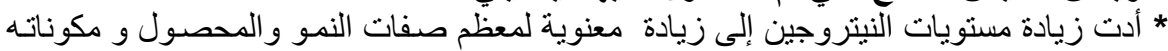

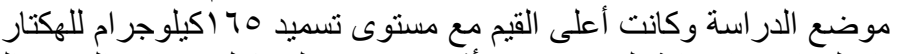

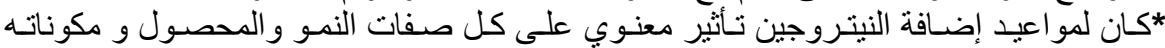

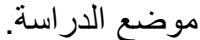

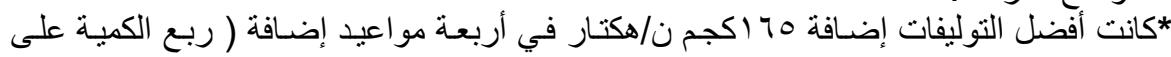

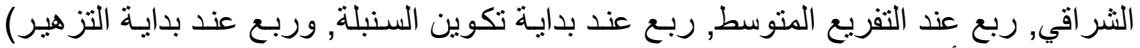

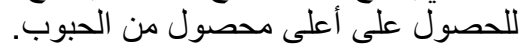

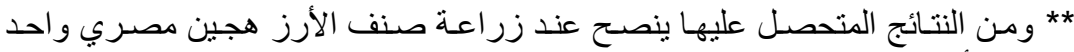

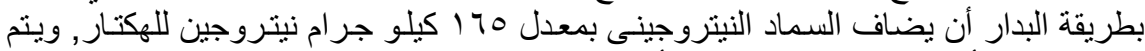

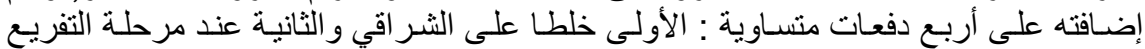

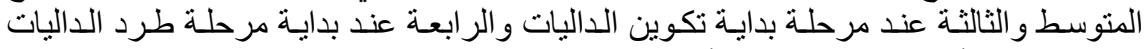
للحصول على أعلى محصول من الأرز تحت ظروف لـن هذه الدراسة.

كلية الزراعة - جامعة المنصورة مركز البحوث الزراعية

قام بتحكيم البحث

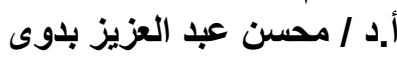

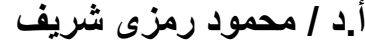

